\title{
İlköğretim Matematik Öğretmeni Adaylarının 21. Yüzyıl Becerilerine Yönelik Metaforik Algilari ${ }^{a}$
}

\author{
Gülenaz Selçukb, c,
}

\section{Özet}

$\mathrm{Bu}$ çalışmada, ilköğretim matematik öğretmeni adaylarının 21. yüzyıl becerilerine yönelik metaforik algıları incelenmiştir. Araştırmanın çalışma grubunu, Ege Bölgesi'nde yer alan bir devlet üniversitesinin eğitim fakültesi ilköğretim matematik öğretmenliği programında öğrenim gören 49 matematik öğretmen adayı oluşturmaktadır. Nitel araştırma yöntemlerinden olgu bilim desenine göre tasarlanan çalışmada, verilerin analizinde içerik analizinden yararlanılmıştır. Veriler, öğretmen adaylarının 21. yüzyıl becerileri kapsamında; "öğrenme ve yenilik becerileri", "bilgi, medya ve teknoloji becerileri", "yaşam ve kariyer becerileri" şeklinde kategorize edilen üç temel beceri alanına yönelik metaforik algılarını belirlemek amacıyla araştırmacı tarafından geliştirilmiş açık uçlu sorulardan oluşan bir veri toplama aracı kullanılarak toplanmıştır. Verilerin analizi sonucunda öğretmen adaylarının en çok "oyun hamuru" metaforunu ( $\mathrm{f}=10)$ kullandığı görülmüştür. $\mathrm{Bu}$ metafordan sonra "lastik" (f=7), "bitki yetiştirmek" ( $\mathrm{f}=7$ ), "gezmek" ( $\mathrm{f}=6)$, "yemek yapmak" ( $f=5)$ "süzgeç" ( $f=5)$, "araba kullanmak" ( $f=5)$, "köprü" ( $f=4)$, "bukalemun" ( $\mathrm{f}=4)$, "resim çizmek" ( $\mathrm{f}=4$ ) ve "kütüphane" ( $\mathrm{f}=4$ ) metaforlarının da üretildiği tespit edilmiştir.
Anahtar Kelimeler

21. Yüzyıl Becerileri

Öğretmen Adayları

Metafor

Makale Hakkında

Geliş Tarihi: 31.10 .2020

Kabul Tarihi: 25.12.2020

Doi: $10.18026 /$ cbayarsos. 819188

\section{Metaphoric Perceptions of Primary Mathematics Teacher Candidates Towards $21^{\text {st }}$ Century Skills}

\begin{abstract}
In this study, metaphorical perceptions of mathematics teacher candidates

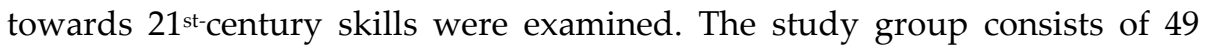
mathematics teacher candidates studying in the education faculty primary school mathematics teaching program of a state university in the Aegean Region. In the study designed according to phenomenology pattern, one of the qualitative research methods, content analysis was used in the analysis of the data. The data was collected using a data collection tool consisting of openended questions developed by the researcher in order to determine metaphorical perceptions of three basic skill areas within the scope of 21stcentury skills of teacher candidates categorized as "learning and innovation skills", "information, media and technology skills", "life and career skills". As a result of the analysis of the data, it was seen that the teacher candidates mostly used the "play dough" metaphor $(f=10)$. Other than that, "rubber" $(f=$ 7), "growing plants" ( $f=7)$, "traveling" ( $f=6)$, "cooking" ( $f=5)$ "strainer" $(f=5)$, "driving a car" ( $f=5)$, "bridge" ( $f=4)$, "chameleon" ( $f=4)$, "drawing pictures" ( $f$ $=4)$ and "library" $(\mathrm{f}=4)$ are the other produced metaphors.
\end{abstract}

\author{
Keywords \\ $21^{\text {st }}$ Century Skills \\ Pre-service Teachers \\ Metaphor \\ About Article \\ Received: 31.10.2020 \\ Accepted: 25.12.2020
}

Doi: $10.18026 /$ cbayarsos. 819188

\footnotetext{
a Bu çalışma 24-27 Nisan 2019 tarihlerinde Muğla'da düzenlenen 3. Uluslararası Sınırsız Eğitim ve Araştırma Sempozyumu (USEAS 2019)' da sözlü bildiri olarak sunulmuştur.

b İletişim Yazarı: gselcuk@hotmail.com

c Dr. Öğr. Üyesi, Manisa Celal Bayar Üniversitesi, Eğitim Fakültesi, Eğitim Bilimleri Bölümü. ORCID: 0000-0002-3578-6010.
} 


\section{Giriş}

Bilgi çağında öğrencilerin başarılı olabilmeleri için gerekli olan öğrenme yaklaşımları ve üst düzey beceriler genel olarak 21. yüzyıl becerileri şeklinde ifade edilmektedir. Eleştirel düşünme, problem çözme, iş birliği, etkili iletişim, motivasyon ve öğrenmeyi öğrenme gibi birtakım beceriler de 21. yüzyıl becerileri kapsamında ele alınmaktadır (Pellegrino \& Hilton, 2012). Değişimlere uyum sağlamak, teknolojiyi yakalayabilmek, elde edilen bilgileri analiz ederek değerlendirebilmek ve günlük yaşama entegre edebilmek noktasında 21. yüzyıl beceri ve yeterlikleri oldukça önemli görülmektedir.

Silva (2009); uygulamalı beceriler, yaşam becerileri, işgücü becerileri, kişilerarası beceriler ve bilişsel olmayan becerileri de kapsayacak şekilde 21. yüzyıl becerilerini bir beceri seti olarak ifade etmektedir. Fadel, Bialik \& Trilling (2015) ise 21. yüzyıl becerilerini; yaratıcllık, eleştirel düşünme, iletişim, iş birliği ve işe koşmayı öğrenme başlıklarında ele almışlardır. Öte yandan 21. yüzyıl becerilerinin; bilişsel beceriler (yaratıcılık, eleştirel düşünme, problem çözme), kişilerarası beceriler (zorluklarla baş etme, sosyal beceriler, iletişim becerileri, kültürel duyarlılık, ekip çalışması) ve içsel beceriler (yaşam boyu öğrenme, öz yönetim, öz düzenleme, uyumluluk, zaman yönetimi, kişisel gelişim) şeklinde kategorize edildiği de görülmektedir (Yalçın, 2018). Ayrıca 21. yüzyıl becerilerini; ATCS (Assessment and Teaching of 21st Century Skills), P21 (Partnership for 21st Century Learning), OECD (Organization for Economic Cooperation and Development), ASIA Society (Asia Society Partnership for Global Learning), ISTE (International Society for Technology in Education), NCREL (North Central Regional Educational Laboratory), EU (European Union) gibi farklı kurum ve kuruluşlar da değişik şekillerde sınıflandırmışlardır (Anagün, Atalay, Kılıç \& Yaşar, 2016). Bu sınıflamalar arasında Partnership for 21st Century Skills-P21, adıyla bilinen çalışma en yaygın olandır. P21, 2002 yılında Birleşmiş Milletler hükümeti ile özel sektör (Apple, Cisco, Dell, Microsoft ve National Education Association gibi) kuruluşları tarafından yapılandırılmış ve 21. yüzyıl yeterlikleri oluşturmayı hedefleyen Amerika'da kurulmuş ulusal bir organizasyondur. Bu organizasyon; küresel ve dijital dünyada tüm öğrenenlerin başarılı olabilmesi için okuldaki kazanım ve kariyerlerinin ötesinde bilgi ve beceriler üretmelerinin gerekliliğini de savunmaktadır. Bu doğrultuda P21, küresel iş çevrelerinden oluşan üyeleri kanıta dayalı eğitim politikaları üretmek ve her öğrenenin bunları öğrenip uygulayabilmesini sağlamak amacıyla bir araya getirmektedir (Çınar, 2019). P21'e göre bireylerin karmaşık görevleri, düşünmeyi ve iletişimi yerine getirmesini sağlayan yeterlikler 21. yüzyıl becerileri olarak adlandırılmaktadır. P21'e göre 21. yüzyıl becerileri, temel becerileri kapsamakla birlikte; "öğrenme ve yenilik becerileri", "bilgi, medya ve teknoloji becerileri", "yaşam ve kariyer becerileri" olmak üzere üç ana beceri alanından oluşmaktadır (Partenrship for 21 st century Skills, 2019). Öğrenme ve yenilik becerileri: "eleştirel düşünme ve sorun çözme", "yaratıcılık ve yenilik", "iletişim ve işbirliği"; bilgi, medya ve teknoloji becerileri: "bilgi okuryazarlığ1", "medya okuryazarlığı", "BİT (bilgi, iletişim ve teknoloji) okuryazarlığı" ve yaşam ve kariyer becerileri: "esneklik ve uyarlanabilirlik", "girişim ve kendine yön verme becerisi", "sosyal ve kültürler arası beceriler", "verimlilik ve hesap verebilirlik", "liderlik ve sorumluluk" alt boyutlarından oluşmaktadır (Trilling \& Fadel, 2009; Partenrship for 21 st century Skills, 2019).

Öğrenme ve yenilik becerileri kategorisinde yer alan eleştirel düşünme ve sorun çözme alt boyutunda: etkin bir biçimde düşünme, sistemli düşünme, hüküm ve karar verebilme, problem çözme yeterlikleri ön plana çıkarken yaratıcılık ve yenilik alt boyutunda yaratıcı düşünme, başkalarıyla yaratıcı bir biçimde çalışabilme ve yaratıcılığı uygulama yeterlikleri; 
iletişim ve iş birliği alt boyutunda ise net bir biçimde iletişim kurma ve başkaları ile iş birliği yapma yeterlikleri yer almaktadır. Bilgi, medya ve teknoloji becerileri kategorisinde yer alan bilgi okuryazarlığı alt boyutunda: bilgiye erişebilme ve değerlendirebilme, bilgiyi kullanabilme yeterlikleri; medya okuryazarlığı alt boyutunda medyayı analiz edebilme, medya ürünleri üretebilme yeterlikleri; BİT (bilgi, iletişim ve teknoloji) okuryazarlığı alt boyutunda ise teknolojiyi etkin bir şekilde kullanabilme yeterlikleri bulunmaktadır. Yaşam ve kariyer becerileri kategorisinde yer alan esneklik ve uyarlanabilirlik alt boyutunda: değişime uyum sağlayabilme, esnek olma yeterlikleri; girişim ve kendine yön verme becerisi alt boyutunda hedeflerini ve amaçlarını yönetebilme, bağımsız çalışabilme öz-yönetimi olan bir öğrenen olma yeterlikleri; sosyal ve kültürler arası beceriler alt boyutunda başkalarıyla etkin bir şekilde iletişim kurabilme, çeşitli takımlarda etkin çalışabilme yeterlikleri; verimlilik ve hesap verebilirlik alt kategorisinde proje yönetebilme, sonuç üretebilme yeterlikleri; liderlik ve sorumluluk alt kategorisinde ise başkalarını yönlendirebilme ve sorumlu olma yeterlikleri vardır (Çınar, 2019).

21. yüzyıldaki büyük değişimler, eğitim alanındaki beceri ve yeterliklerde de büyük değişikliklere neden olmuştur (Jacobson Lundeberg, 2016). Ülkemizde 2004-2005 eğitim öğretim yılında uygulamaya geçilen eğitim programında; eleştirel düşünme, problem çözme, iletişim, girişimcilik gibi becerilere yer verilmiş ve yapılandırmacı yaklaşımla birlikte öğretmen öğrenmeyi-öğreten rehber konumuna gelmiştir (Anagün ve diğ., 2016). Bunun yanında Millî Eğitim Bakanlığı 2017-2023 (MEB, 2017) Öğretmen Strateji Belgesinde; eğitimin temel amaçlarının gerçekleşmesinde ve bireylerin 21. yüzyıl becerileri olarak nitelendirilen özellikleri kazanmalarında öğretmenlerin önemli rol oynadıkları vurgulanmaktadır. Ayrıca Öğretmen Strateji Belgesinde: “Günümüz dünyasında öğrenmeyi öğrenme, problem çözme, takım üyesi olma ve eleştirel düşünme ile bilgi ve iletişim teknolojilerini kullanma yetkinliği öğrencilere kazandırılması gereken temel beceriler olarak ön plana çıkmıştır. Bu beceri ve değerlerin öğrencilere kazandırılması hususunda öğretmenlere yeni görevler yüklenmiştir. Değişimi okuyabilmek, sürekli gelişmek, empati yapabilmek, etkili iletişim kurabilmek, problem çözmek ve örnek kişilik ve uzmanlık yoluyla sosyal kabul görmek gibi liderlik becerileri, öğretmenliğin mesleki özelliklerinin bütünleşik bir parçası olmuştur. Millî kültüre sağlam bir şekilde kök salmış ancak tüm dünya ile barışık, entelektüel yönden gelişmiş, estetik duygusu olan ve gücünü oluşturduğu etkiden alan bu yeni öğretmen modelinde mesleki saygınlık ve statü, toplumsal ve kültürel değerlerin yanında liderlik becerileri üzerine kurulu uzman gücüne dayanmaktadır" (MEB, 2017) ifadeleri de yer almaktadır.

Diğer önemli bir nokta ise, eğitim- öğretim sisteminin en önemli öğesi olan öğretmenliğe bakış açısının değişmesi sonucunda sahip olunan bilginin günlük hayatta kullanabilmesi ve ürüne dönüştürebilmesi için 21. yüzyıl becerilerine de ihtiyaç olduğudur (Anagün \& diğ., 2016). Öğrencilerde istendik davranışların gelişebilmesi için, öğretme-öğrenme yaşantılarının öğretmenler tarafından etkili bir şekilde düzenlenmesi gerekir. Doğru bir şekilde tasarlanan öğretme-öğrenme yaşantıları; öğrenenlerin bilgi, tutum ve becerilerini geliştirerek sorgulayıcı, eleştirel ve yaratıcı düşünmeye sevk edecektir. Bu amacı gerçekleştirmek için öğretmenlerin farklı yöntem - teknik ve strateji uygulamaları bulunmaktadır (Selçuk, 2018). Son yıllarda eğitim alanındaki kavramların öğretilmesinde oldukça yaygın olarak kullanılan uygulamalardan biri de metaforlardır (Selçuk, 2018; Çetinkaya \& Eskici, 2018). Metaforlar; kavram ve terimlerin öğrenilmesini kolaylaştıran, soyut kavramların somutlaştırılması ve görselleştirmesinde kullanılan bir düşünce ve görme biçimidir (Morgan, 1998). Lakoff \& Johnson (2005) da metaforu; "başka bir şeye göre anlamak, bir şeyi başka bir şeye benzetmek ve tecrübe etmek" olarak ifade etmektedir (Selçuk, 2018). Gezer (2006) de metaforun 
öğrencilerin dış dünyaya bakış açısını değiştirme gibi güçlü bir özelliğe sahip olduğunu vurgulamaktadır. Metaforlarla ilgili yapılan çalışmaların (Aydın \& Pehlivan, 2010; Balcı, 2011; Bülbül \& Gökçe Toker, 2015; Cerit, 2008; Çetinkaya \& Eskici, 2018; Çırak, 2014; Durukan, Hacıŏlu \& Dönmez Usta, 2016; Dündar \& Karaca, 2013; Kaya, 2014; Korkmaz \& Ünsal, 2016; Martinez, Sauleda \& Huber, 2001; Massengill \& Mahlios, 2008; Nalçacı \& Bektaş, 2012; Örten \& Erginer, 2016; Örücü, 2014; Özbaş \& Aktekin, 2013; Özdemir \& Akkaya, 2013; Saban, 2009; Seferoğlu, Korkmazgil \& Ölçü, 2009; Selçuk, 2018; Semerci, 2007; Thomas \& Beauchamp, 2011; Tünkler, Tarman \& Güven, 2016; Yob, 2003; Yüner \& Özdemir, 2017) son yıllarda eğitim bilimleri alanında da arttığı görülmektedir. Çalışmalardaki artışın altında, bireylerin anlamlandırma ve yapılandırmalara süreçlerinde metaforların güçlü bir zihinsel haritalama ve modelleme aracı olarak kullanılması yatmaktadır (Arslan \& Bayrakçı, 2006).

Öte yandan alanyazın incelendiğinde 21. yüzyıl becerilerine yönelik çalışmaların (Anagün \& diğ., 2016; Başar, 2018; Beers, 2011; Çınar, 2019; Çolak, 2018; DiCerbo, 2014; Eker, Akar Elekoğlu, Kamar \& Kamar, 2019; Ekici, Abide, Canbolat \& Öztürk, 2017; Erdoğan, 2020; Eryılmaz \&Uluyol, 2015; Göksün \& Kurt, 2017; Gürültü, Aslan \& Alc1, 2018; JacobsonLundeberg, 2016; Kay \& Greenhill, 2011; Kaya, 2017; Keskin \& Yazar, 2015; Kozikoğlu \& Altunova, 2018; Kuzu, Günüç \& Odabaşı, 2013; Lai \& Viering, 2012; Larson \& Miller, 2011; Murat, 2018; Orhan Göksün, 2016; Pellegrino \& Hilton, 2012; Silva, 2009; Soland, Hamilton \& Stecher, 2013; Trilling \& Fadel, 2009; Yalçın, 2018; Yeni, 2018) yer aldığ1 görülmektedir. Ancak ilköğretim matematik öğretmeni adaylarının 21. yüzyıl temel beceri alanlarına yönelik metaforik algılarına yönelik çalışmalara rastlanılmamıştır. Bu araştırmayla, Türkiye'de ilköğretim matematik öğretmeni adaylarının 21. yüzyıl temel beceri alanlarına yönelik metaforik algılarının ortaya çıarılmaya çalışılmasının literatüre katkı sağlayacağ düşünülmektedir.

Buradan hareketle bu çalışmanın amacı, ilköğretim matematik öğretmeni adaylarının 21. yüzyıl becerileri kapsamında; "öğrenme ve yenilik becerileri”, "bilgi, medya ve teknoloji becerileri", "yaşam ve kariyer becerileri" şeklinde kategorize edilen üç temel beceri alanına yönelik metaforik algılarını incelemektir. Bu amaç doğrultusunda aşağıdaki alt problemlere cevap aranmıştır:

1. 21. yy. "öğrenme ve yenilik becerileri" temel beceri alanı kapsamında; öğretmen adaylarının "eleştirel düşünme ve sorun çözme", "yaratıcılık ve yenilik", "iletişim ve iş birliği" alt kategorilerinde ürettikleri metaforlar nelerdir?

2. 21. yy. "bilgi, medya ve teknoloji becerileri" temel beceri alanı kapsamında; öğretmen adaylarının "bilgi okuryazarlığı", "medya okuryazarlığı", "BİT (bilgi, iletişim ve teknoloji) okuryazarlığı" alt kategorilerinde ürettikleri metaforlar nelerdir?

3. 21. yy. "yaşam ve kariyer becerileri" temel beceri alanı kapsamında; öğretmen adaylarının "esneklik ve uyarlanabilirlik", "girişim ve kendine yön verme becerisi", "sosyal ve kültürler arası beceriler", "verimlilik ve hesap verebilirlik", "liderlik ve sorumluluk" alt kategorilerinde ürettikleri metaforlar nelerdir? 


\section{Yöntem}

$\mathrm{Bu}$ bölümünde araştırmanın modeli, çalışma grubu, veri toplama aracı ve verilerin toplanması, geçerlik-güvenirlik ve verilerin analizi yer almaktadır.

\section{Araştırma Modeli}

$\mathrm{Bu}$ çalışmada, nitel araştırma yöntemlerinden olgu bilim desen kullanılmıştır. Olgu bilim desen; insanların yaşadıkları deneyimleri nasıl anlamlandırdıklarını, nasıl algıladıklarını ve zihinlerine nasıl transfer ettiklerini, nasıl hatırladıklarını ve diğer insanlara ne şekilde ifade ettiklerinin araştırılmasıdır (Yıldırım \& Şimşek, 2013). Çalışmada öğretmen adaylarının 21. yüzyıl becerilerine yönelik algılarını ortaya çıkarmak amacıyla metafor uygulaması gerçekleştirilmiştir. Bu nedenle olgu bilim deseni tercih edilmiştir. Ayrıca araştırmalarda nitel veri toplama aracı olarak kullanılan metaforlar, zengin bulgular elde edilmesine de olanak sağlamaktadır (Patton, 2002).

\section{Çalışma Grubu}

Araştırma amaçlı örnekleme yöntemlerinden kolay ulaşılabilir durum örneklemesi kullanılarak gerçekleştirilmiştir. Amaçlı örnekleme yöntemleri pek çok durumda, olgu ve olayların keşfedilmesinde ve açıklanmasında yararlı olmaktadır. Araştırmacılar kolay ulaşılabilir bir grubu maliyet ve ulaşılabilirlik açısından tercih ettikleri için nitel araştırmalarda "kolay ulaşılabilir durum örneklemesi" yaygın olarak kullanılan bir örnekleme yöntemidir (Yıldırım \& Şimşek, 2013).

Araştırmada 49 öğretmen adayı gönüllü olarak veri toplama aracını doldurmuştur. Çalışma grubuna ait demografik değişkenler Tablo 1 'de yer almaktadır.

Tablo 1. Çalışma Grubuna Ait Demografik Değişkenler

\begin{tabular}{|c|c|c|c|}
\hline Değişken & Özellik & $f$ & $\%$ \\
\hline \multirow[t]{2}{*}{ Cinsiyet } & Kadın & 36 & 73,47 \\
\hline & Erkek & 13 & 26,53 \\
\hline Yaş & $18-23$ & 49 & 100 \\
\hline \multirow{5}{*}{ Mezun Olunan Lise Türü } & Anadolu Lisesi & 23 & 46,94 \\
\hline & Anadolu Öğretmen Lisesi & 16 & 32,65 \\
\hline & Fen Lisesi & 3 & 6,12 \\
\hline & Genel Lise & 2 & 4,08 \\
\hline & Diğer & 5 & 10,21 \\
\hline \multirow{5}{*}{ Ailenin İkamet Ettiği Yer } & Büyükşehir & 20 & 40,82 \\
\hline & İl & 1 & 2,04 \\
\hline & İlçe & 20 & 40,82 \\
\hline & Belde & 1 & 2,04 \\
\hline & Köy & 7 & 14,28 \\
\hline
\end{tabular}

\section{Veri Toplama Aracı ve Verinin Toplanması}

$\mathrm{Bu}$ çalışmada veriler, ilköğretim matematik öğretmeni adaylarının 21. yüzyıl becerileri kapsamında; "öğrenme ve yenilik becerileri”, "bilgi, medya ve teknoloji becerileri", "yaşam ve kariyer becerileri" şeklinde kategorize edilen üç temel beceri alanına yönelik metaforik algılarını belirlemek amacıyla araştırmacı tarafından geliştirilmiş açık uçlu sorulardan oluşan bir veri toplama aracı kullanılarak toplanmıştır. Veri toplama aracı iki bölümden 
oluşmaktadır. İlk bölümde öğretmen adaylarının cinsiyet, yaş, mezun olunan lise türü ve ailenin ikamet ettiği yere ilişkin demografik değişkenler yer almaktadır. İkinci bölümde ise; "eleştirel düşünme ve sorun çözme" / "yaratıcılık ve yenilik" / "iletişim ve iş birliği" / "bilgi okuryazarlığı" / "medya okuryazarlığg1" / "bilgi, iletişim ve teknoloji okuryazarlığı" / "esneklik ve uyarlanabilirlik"| "girişim ve kendine yön verme becerisi"/ "sosyal ve kültürler arası beceriler"/ "verimlilik ve hesapverebilirlik"/“liderlik ve

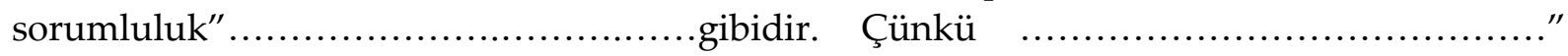
şeklindeki ifadelerinin ayrı ayrı yer aldığı açık uçlu sorular bulunmaktadır. Metafor çalışmalarında yer alan "gibi" kavramı, metaforu ortaya çıkaran bölüm; "çünkü" ise, katılımcıların metaforu mantıklı gerekçelerle açıkladıkları bölümdür (Saban, 2008). Veriler toplanmadan önce öğretmen adaylarına araştırmanın amacı açıklanıp, metaforlarla ilgili açılamalar yapılmış ve örnekler verilmiştir. Öğretmen adaylarının kendi el yazılarıyla kaleme aldıkları görüşler araştırmada bulgularda temel veri kaynağı olarak kullanılmıştır (Selçuk, 2018).

\section{Geçerlik ve Güvenirlik}

Alan yazın tarandıktan sonra taslak form şeklinde veri toplama aracı oluşturulmuştur. Öncelikle taslak formdaki soruların anlaşılırlığını test etmek amacıyla farklı bölümlerde öğrenim gören ve çalışma grubunda yer almayan 10 öğretmen adayına uygulama yapılmıştır. Uygulama sonucunda veri toplama aracının değişiklik yapılmadan mevcut şekliyle kullanılmasına karar verilmiştir. Öğretmen adaylarının “21. yüzyıl becerilerini oluşturan temel becerilerin alt kategorilerine" ilişkin üretmiş oldukları metaforların kategorileri temsil etme durumlarını incelemek için geçerlik ve güvenirlik çalışması yapılmıştır. Öğretmen adaylarından elde edilen veriler iki ayrı uzman tarafından bağımsız olarak analiz edilmiştir. Uzmanların oluşturduğu listeler karşılaştırılarak görüş birliği ve görüş ayrılığı sayıları tespit edildikten sonra, Miles \& Huberman'nın (1994) formülü (Güvenirlik=Görüş birliği/Görüş birliği+Görüş ayrılığ x 100) kullanılmıştır. Nitel bir araştırmada güvenirliğin sağlanması için araştırmacılar arasındaki uyumun en az \%80 olması gerekmektedir (Creswell, 2016). Bu doğrultuda yapılan güvenilirlik analizi sonucunda çalışmanın güvenilirliği 0,85 olarak hesaplanmıştır. Buradan hareketle araştırmanın geçerlik ve güvenirliğini sağladığı görülmektedir.

\section{Verilerin Analizi}

Öğretmen adaylarının 21. yüzyıl becerilerine yönelik üretmiş oldukları metaforlar içerik analizi tekniği kullanılarak analiz edilmiştir. İçerik analizinde temel amaç toplanan verileri anlamlandırabilecek kavramlara ve ilişkilere ulaşmaktır (Yıldırım \& Şimşek, 2013). Çalışmada, verilerin analizi sürecinde katılımcı olarak öğretmen adaylarını ifade ederken (ÖA,1), (ÖA,2),........(ÖA,49) şeklinde kodlar kullanılmıştır. Bu çerçevede öğretmen adayları tarafından geliştirilen metaforlar içerik analiz yöntemi kullanılarak analiz edilmiştir (Saban, 2009). İlk aşamada öğretmen adaylarının üretmiş oldukları metaforlar araştırmacı tarafından oluşturulan ve elektronik ortamda yer alan veri toplama formuna işlenmiştir. İkinci aşama olan eleme aşamasında geçersiz metafor olmadığı için eleme yapılmamıştır. Üçüncü aşamada öğretmen adaylarının 21. yüzyıl becerilerini oluşturan temel becerilerin alt kategorilerine yönelik ayrı ayrı ürettikleri metaforlar ortak özellikleri bakımından; “öğrenme ve yenilik 
becerileri", "bilgi, medya ve teknoloji becerileri", "yaşam ve kariyer becerileri" şeklinde kategorize edilen üç temel beceri alanlarına göre kategorileri oluşturulmuştur. Dördüncü aşamada ise uzman görüşleri doğrultusunda geçerlik ve güvenirlik çalışması yapılmıştır. Beşinci ve son aşamada elde edilen metaforların frekansları hesaplanarak oluşturulan kategorilere uygun tablolar yapılmış ve veriler yorumlanmıştır.

\section{Bulgular}

Çalışmanın bu bölümünde, verilerin analizi sonucunda elde edilen bulgular yer almaktadır.

Birinci Alt Probleme İlişkin Bulgular

Araştırmanın birinci alt problemi 21. yüzyıl "öğrenme ve yenilik becerileri” temel beceri alanı kapsamında; öğretmen adaylarının "eleştirel düşünme ve sorun çözme", "yaratıcllık ve yenilik", "iletişim ve iş birliği" alt kategorilerinde ürettikleri metaforlar nelerdir? şeklindedir. Tablo 2'de öğretmen adaylarının "eleştirel düşünme ve sorun çözme" kategorisine yönelik metafor algılarının frekans dağılımı yer almaktadır.

Tablo 2. Öğretmen adaylarının "eleştirel düşünme ve sorun çözme" kategorisine yönelik ürettikleri metaforlar

\begin{tabular}{|c|c|c|c|c|c|c|c|c|}
\hline \multirow{21}{*}{ 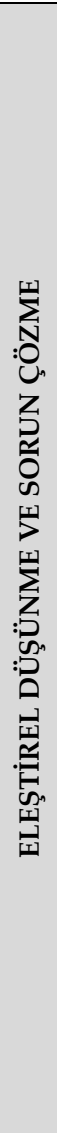 } & METAFOR & $f$ & \multirow{21}{*}{ 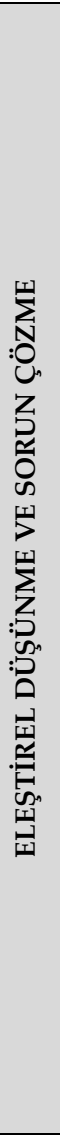 } & METAFOR & $f$ & \multirow{21}{*}{ 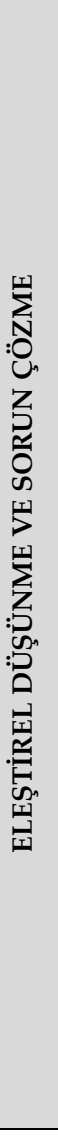 } & METAFOR & $f$ \\
\hline & Teknoloji & 1 & & Bulmaca & 1 & & Mahkemeye Çıkmak & 1 \\
\hline & Çürük Kiraz & 1 & & Ağaçların Meyve Dökmesi & 1 & & Hayat Belirtisi & 1 \\
\hline & Patos & 1 & & Zekâ & 1 & & Cinayet Çözmek & 1 \\
\hline & $\begin{array}{l}\text { Çürük Meyve } \\
\text { Ayıklamak }\end{array}$ & 1 & & Süzgeç & 1 & & Özgüven & 1 \\
\hline & Puzzle Yapmak & 1 & & $\begin{array}{l}\text { Bilgisayar Virüsü } \\
\text { Temizlemek }\end{array}$ & 1 & & $\begin{array}{c}\text { Aynı Şarkıyı Farklı } \\
\text { Sanatçıların } \\
\text { Söylemesi } \\
\end{array}$ & 1 \\
\hline & Özel Ders Vermek & 1 & & Nehir & 1 & & & \\
\hline & Karda Yürümek & 1 & & Ayna & 1 & & & \\
\hline & $\begin{array}{l}\text { Bir Adım Geriden } \\
\text { Bakmak }\end{array}$ & 1 & & Çiçek Yetiştirmek & 1 & & & \\
\hline & Yağ & 1 & & Kıyafet Seçmek & 1 & & & \\
\hline & Kavga Etmek & 1 & & İlaç & 1 & & & \\
\hline & $\begin{array}{c}\text { Büyük Bir Resme } \\
\text { Bakmak } \\
\end{array}$ & 1 & & $\begin{array}{c}\text { Bozulan Televizyonu Tamir } \\
\text { Etmek }\end{array}$ & 1 & & & \\
\hline & Yapboz & 1 & & Ağaçların Yaprak Dökmesi & 1 & & & \\
\hline & Un Elemek & 2 & & Yeni Biriyle Tanışmak & 1 & & & \\
\hline & Düğüm Çözmek & 3 & & Proje & 1 & & & \\
\hline & Karışan İpleri Ayırmak & 1 & & $\begin{array}{l}\text { Mikroskopla Hücre } \\
\text { İncelemek }\end{array}$ & 1 & & & \\
\hline & Elek & 1 & & Kazı Yapmak & 1 & & & \\
\hline & Ebeveyn & 2 & & Matematik & 1 & & & \\
\hline & $\begin{array}{l}\text { Samanlıkta iğne } \\
\text { aramak }\end{array}$ & 1 & & Deniz Kabuğu Toplamak & 1 & & & \\
\hline & Bilgelik & 1 & & $\begin{array}{c}\text { Meyvenin Çürük Yanını } \\
\text { Kesmek } \\
\end{array}$ & 1 & & & \\
\hline & Pusula & 1 & & Gözlük Kullanmak & 1 & & TOPLAM & 49 \\
\hline
\end{tabular}

Tablo 2'de öğretmen adaylarının "eleştirel düşünme ve sorun çözme" kategorisine yönelik ürettikleri metaforlar frekans dağılımlarına göre incelendiğinde "dügüum çözmek (f=3)" en çok tercih edilen metafordur. Bu metaforun ardindan "un elemek $(\mathrm{f}=2)$ " ve "ebeveyn $(\mathrm{f}=2)$ " metaforları gelmektedir. Diğer metafor imgelerin frekans değerleri ise 1' dir. Öğretmen 
adaylarının "eleştirel düşünme ve sorun çözme" kategorisine ilişkin ifadelerden bazıları aşağıdaki şekildedir.

- "Eleştirel düşünme ve sorun çözme, dü̈̆̈̈̈m çözmek gibidir. Çünkü bir düğ̈̈mü eleştirel yaklaşıp doğru açılardan incelemeden çözmeye çalışırsak kör düğ̈̈m olur." (ÖA, 14)

- "Eleştirel düşünme ve sorun çz̈zme, un elemek gibidir. Çünkü unu elerken nasıl ki pislikleri ayıklayıp temiz bir ürün elde ediyorsak sorunlara da eleştirel yaklaştığımızda çözüme daha kolay ulaşırız." (ÖA, 13)

- "Eleştirel düşünme ve sorun çözme, ebeveyn gibidir. Çünkü ebeveyn sorunun çözümüne ulaşmak noktasında eleştirel bakış açısıyla her şeyi en ince ayrıntısına kadar ve her yönüyle düşünür." (ÖA, 17)

- "Eleştirel düşünme ve sorun çözme, yapboz gibidir. Çünkü eleştirel düşünmeyi kullanarak parçaları birleştirince resmi daha net görürüz." (ÖA, 12)

- "Eleştirel düşünme ve sorun çözme, bulmaca çözmek gibidir. Çünkü bulmacayı çözdükçe sonuca adım adım yaklaşırsın." (ÖA, 21)

- "Eleştirel düşünme ve sorun çözme, bozulan televizyonu tamir etmek gibidir. Çünkü sorunun ne olduğunu düşünüp ona göre çözüme ulaşırız." (ÖA, 34)

Tablo 3'de öğretmen adaylarının "yaratıcılık ve yenilik" kategorisine yönelik metafor algılarının frekans dağılımı yer almaktadır.

Tablo 3. Öğretmen adaylarının “yaratıcılık ve yenilik" kategorisine yönelik ürettikleri metaforlar

\begin{tabular}{|c|c|c|c|c|c|c|c|c|}
\hline \multirow{16}{*}{ 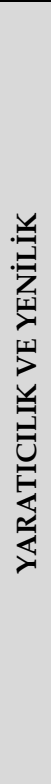 } & METAFOR & $f$ & \multirow{16}{*}{ 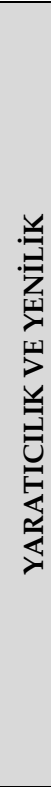 } & METAFOR & $f$ & \multirow{16}{*}{ 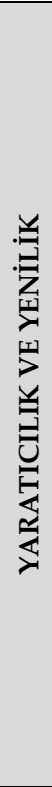 } & METAFOR & $f$ \\
\hline & Doyumsuzluk & 1 & & Soda & 1 & & Yetenek & 1 \\
\hline & $\begin{array}{c}\text { Eve Kisa Yoldan } \\
\text { Gitmek }\end{array}$ & 1 & & Oyun & 1 & & Telefon & 1 \\
\hline & Denizaltında Dolaşmak & 1 & & Meyve Ağacı & 1 & & Yükselmek & 1 \\
\hline & Çocuk Olmak & 3 & & $\begin{array}{c}\text { Renkleri Karıştırıp Turuncu } \\
\text { Elde Etmek }\end{array}$ & 1 & & Gökkuşağ1 & 1 \\
\hline & Resim Çizmek & 4 & & Yemek Yemek & 1 & & Yalan Söylemek & 1 \\
\hline & Fotoğraf Çekmek & 1 & & Doğa & 1 & & Proje Oluşturmak & 1 \\
\hline & İlkbaharın Gelişi & 1 & & Modaya Uymak & 1 & & $\begin{array}{l}\text { Yılanın Kabuk } \\
\text { Değiştirmesi }\end{array}$ & 1 \\
\hline & $\begin{array}{c}\text { Farklılığı Ortaya } \\
\text { Çıkarmaktır }\end{array}$ & 1 & & Ağaç Sulamak & 1 & & Ateşi Bulmak & 1 \\
\hline & Marangoz & 1 & & Terzinin Makası & 1 & & Bilim Adamı & 1 \\
\hline & Robotik Programlama & 1 & & Tohum Ekmek & 1 & & & \\
\hline & Yemek Yapmak & 5 & & Kalem & 1 & & & \\
\hline & Çağdaş İnsan & 1 & & Deney Yapmak & 2 & & & \\
\hline & Hayal Kurmak & 1 & & Farklı Açılardan Bakabilmek & 1 & & & \\
\hline & Bebek Doğurmak & 1 & & Tuzlu Yemek & 1 & & & \\
\hline & Konserve Açacağ 1 & 1 & & Nefes Almak & 1 & & TOPLAM & 49 \\
\hline
\end{tabular}

Tablo 3'de öğretmen adaylarının "yaratıcılık ve yenilik" kategorisine yönelik ürettikleri metaforlar frekans dağılımlarına göre incelendiğinde "yemek yapmak $(\mathrm{f}=5)$ " en çok tercih edilen metafordur. Bu metaforun ardından "resim çizmek ( $\mathrm{f}=4)$ " ve "çocuk olmak $(\mathrm{f}=3)$ " metaforları gelmektedir. Diğer metafor imgelerin frekans değerleri ise 1 ve 2 ' dir. Öğretmen adaylarının "yaratıcılık ve yenilik" kategorisine ilişkin ifadelerden bazıları aşağıdaki şekildedir. 
- "Yaratıcılık ve yenilik, yemek yapmak gibidir. Çünkü bizim yaratıcılığımızla kullanacağımız malzemelerden yeni bir ürün ortaya çıkar." (ÖA, 34)

- "Yaratıcılık ve yenilik, yemek yapmak gibidir. Çünkü aynı malzemelerden farklı görüntülerde ve tatlarda yiyecekler yapabiliriz." (ÖA, 37)

- "Yaratıcılık ve yenilik, resim çizmek gibidir. Çünkü resim yapmaya başlayınca hiç aklımızda olmayan yeni şeyler ortaya çıkar tıpkı yaratıcılık gibi." (ÖA, 18)

- "Yaratıcllık ve yenilik, çocuk olmak gibidir. Çünkü çocuk sürekli gelişim sürecindedir, içerisinde öğrenme istek ve merak vardır." (ÖA, 41)

- "Yaratıcılık ve yenilik, fotoğraf çekmek gibidir. Çünkü bir kareyi yakalamak için farklı açılara ve yeni uyumlara açı olmak gereklidir." (ÖA, 6)

- "Yaratıcıllk ve yenilik, telefon gibidir. Çünkü sürekli gelişir ve yeni özellikler eklenir." (ÖA, 47)

Tablo 4' de öğretmen adaylarının “iletişim ve iş birliği” kategorisine yönelik metafor algılarının frekans dağılımı yer almaktadır.

Tablo 4. Öğretmen adaylarının "iletişim ve iş birliği" kategorisine yönelik ürettikleri metaforlar

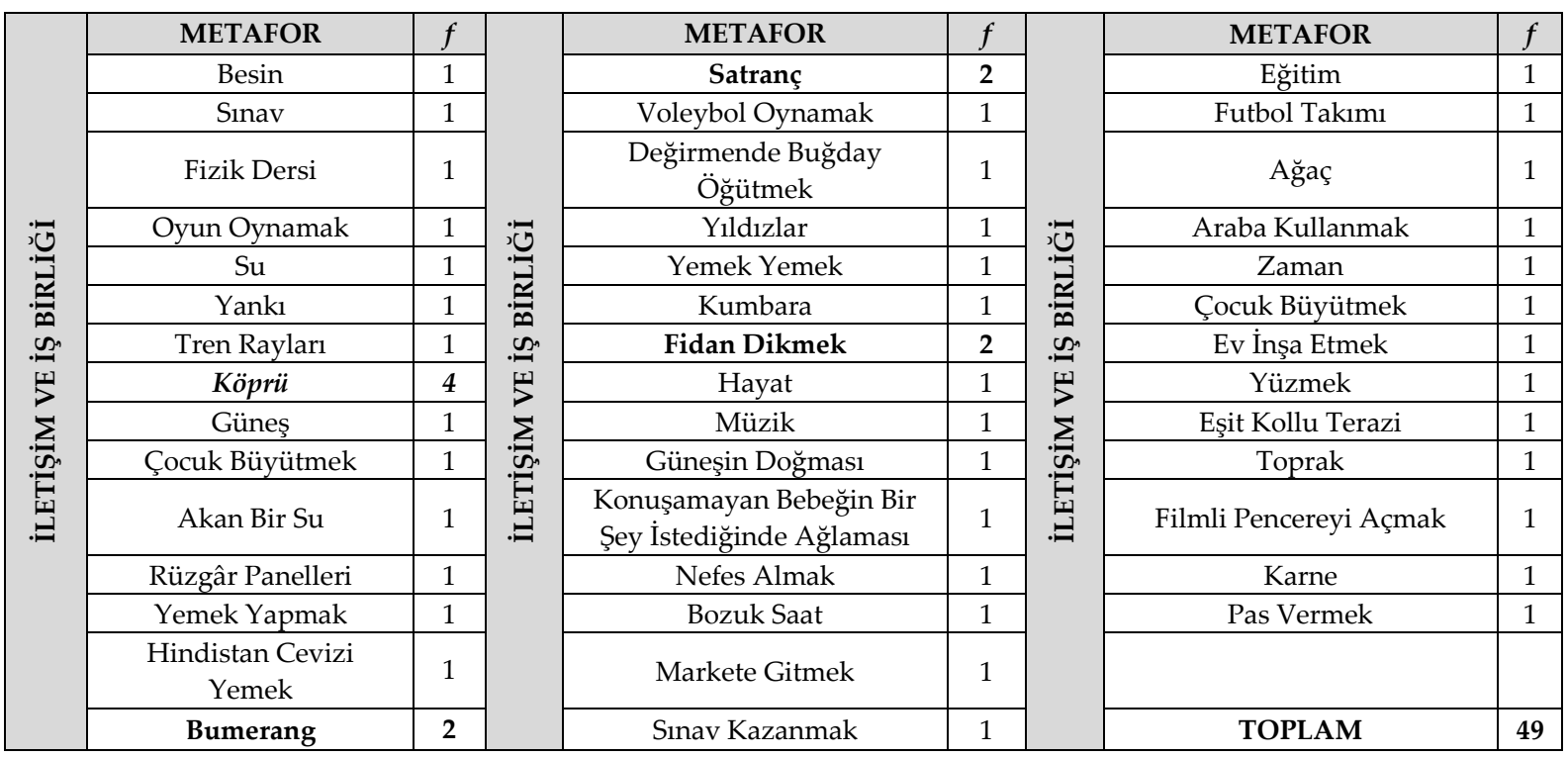

Tablo 4'de öğretmen adaylarının "iletişim ve iş birliği" kategorisine yönelik ürettikleri metaforlar frekans dağılımlarına göre incelendiğinde "köprü $(\mathrm{f}=4)$ " en çok tercih edilen metafordur. Bu metaforun ardından "bumerang $(\mathrm{f}=2)$ ", " $\operatorname{satranç~}(\mathrm{f}=2)$ " ve "fidan dikmek $(\mathrm{f}=2)$ " metaforları gelmektedir. Diğer metafor imgelerin frekans değerleri ise 1' dir. Öğretmen adaylarının "iletişim ve iş birliği" kategorisine ilişkin ifadelerden bazıları aşağıdaki şekildedir.

- "İletişim ve iş birliği, köprü gibidir. Çünkü köprü nasıl yolları birbirine bağlıyorsa iletişim ve iş birliği de insanlarn birbirine bağlar." (ÖA, 36)

- "Illetişim ve iş birliği, köprü gibidir. Çünkü iki taraf arasındaki duygu ve düşüncelerin paylaşılmasına olanak sağlayarak ortak bir bă̆ kurar." (ÖA, 31)

- "İletişim ve iş birliği, bumerang gibidir. Çünkü doğru bir iletişim ve iş birliği nasıl ki olumlu olarak sonuçlanıyorsa bumerang da siz onu firlatırsinız o size geri döner." (ÖA, 15) 
- "İletişim ve iş birliği, fidan dikmek gibidir. Çünkü etkili iletişim ve iş birliği içerisinde gerçekleştirilen çalışmaların başarılı sonuçlara ulaştırdığı gibi diktiğimiz fidanlar da ă̆aç haline geldiğinde her şeyinden yararlanabiliriz." (ÖA, 29)

- "İletişim ve iş birliği, satranç gibidir. Çünkü satrançta taşları hareket ettirerek doğru hamleler yapmak oyunu kazandırıyorsa iletişim ve iş birliği de başarıya ulaştırır." (ÖA, 37)

- "Illetişim ve iş birliği, ev inşa etmek gibidir. Çünkü ev inşa ederken sağlam temel oluşturmak ne kadar önemli ise, iletişim ve iş birliğinde de temeli să̆lam kurmak o kadar önemlidir." (ÖA, 43)

\section{İkinci Alt Probleme İlişkin Bulgular}

Araştırmanın ikinci alt problemi 21. yy. "bilgi, medya ve teknoloji becerileri" temel beceri alanı kapsamında; öğretmen adaylarının "bilgi okuryazarlığı", "medya okuryazarlığı", "BİT (bilgi, iletişim ve teknoloji) okuryazarlığı" alt kategorilerinde ürettikleri metaforlar nelerdir? şeklindedir.

Tablo 5'de öğretmen adaylarının "bilgi okuryazarlı̆̆g” kategorisine yönelik metafor algılarının frekans dağılımı yer almaktadır.

Tablo 5. Öğretmen adaylarının “bilgi okuryazarlığı” kategorisine yönelik ürettikleri metaforlar

\begin{tabular}{|c|c|c|c|c|c|c|c|c|}
\hline \multirow{15}{*}{ 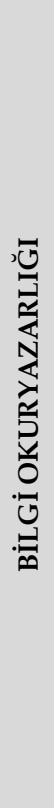 } & METAFOR & $f$ & \multirow{15}{*}{ 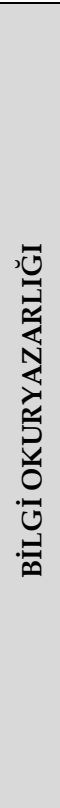 } & METAFOR & $\mathrm{f}$ & \multirow{15}{*}{ 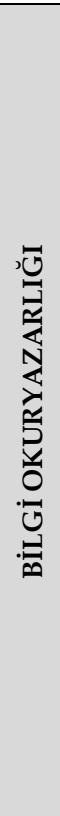 } & METAFOR & $f$ \\
\hline & Google & 3 & & Sözlük & 1 & & Okyanus & 1 \\
\hline & Örgü Örmek & 1 & & $\begin{array}{c}\text { Kendi Mutfağında Yemek } \\
\text { Yapmak }\end{array}$ & 1 & & Yapboz & 1 \\
\hline & Bisiklet Sürmek & 1 & & Spor Yapmak & 1 & & Yemek Yemek & 2 \\
\hline & Analiz Etmek & 1 & & Yağmur & 1 & & Süzgeç & 2 \\
\hline & Dedikodu & 1 & & Ev İnşa Etmek & 2 & & Bilgisayar & 1 \\
\hline & Kitap & 2 & & Yaşam & 1 & & Elma Toplamak & 1 \\
\hline & $\begin{array}{l}\text { Çölde Su } \\
\text { Bulmak }\end{array}$ & 1 & & Musluk & 1 & & Dolu Kutuyu Açmak & 1 \\
\hline & $\begin{array}{c}\text { Doyumsuz } \\
\text { Olmak }\end{array}$ & 1 & & Baraj & 1 & & Araba Kullanmayı Bilmek & 1 \\
\hline & Altın & 1 & & $\begin{array}{c}\text { Çayırda Çıkan Otun } \\
\text { Yenilebileceğini Fark Etmek }\end{array}$ & 1 & & Patoz Kullanmak & 1 \\
\hline & $\begin{array}{c}\text { İnsanı } \\
\text { Tanımak }\end{array}$ & 2 & & Su İçmek & 2 & & Açık Alg1 & 1 \\
\hline & Resim Yapmak & 1 & & Diş Fırçalamak & 1 & & & \\
\hline & Anahtar & 1 & & Kahve & 1 & & & \\
\hline & Kütüphane & 4 & & Pirinç Ayıklamak & 1 & & & \\
\hline & $\begin{array}{l}\text { Ameliyat } \\
\text { Etmek }\end{array}$ & 1 & & Arıtma Suyu & 1 & & TOPLAM & 49 \\
\hline
\end{tabular}

Tablo 5'de öğretmen adaylarının "bilgi okuryazarlığı" kategorisine yönelik ürettikleri metaforlar frekans dağılımlarına göre incelendiğinde "kütüphane $(\mathrm{f}=4)$ " en çok tercih edilen metafordur. Bu metaforun ardından "Google ( $\mathrm{f}=3)$ ", " kitap $(\mathrm{f}=2)$ ”, , insanı tanımak $(\mathrm{f}=2)$ ", , "ev inşa etmek ( $\mathrm{f}=2)$ ”, "su içmek $(\mathrm{f}=2)$ ", "yemek yemek $(\mathrm{f}=2)$ ” ve "süzgeç $(\mathrm{f}=2)$ " metaforları gelmektedir. Diğer metafor imgelerin frekans değerleri ise 1' dir. Öğretmen adaylarının "bilgi okuryazarlığı" kategorisine ilişkin ifadelerden bazıları aşağıdaki şekildedir.

- "Bilgi okuryazarlığı, kütüphane gibidir. Çünkü kütüphanedeki bölümler gibi edinilen her bilginin yeri kendi beynimizde de ayrlarak yer alır." (ÖA, 13) 
- "Bilgi okuryazarlı̆̆ı, kütüphane gibidir. Çünkü giren çok fazla bilgiye ulaşır." (ÖA, 14)

- "Bilgi okuryazarlığı, kütüphane gibidir. Çünkü doğru bilgiye ulaşmak ve yanlış bilgileri de ayıklamak için uğrarız." (ÖA, 34)

- "Bilgi okuryazarlı̆̆ı, google gibidir. Çünkü doğru bilgiyi araştırıp bulmamızı hızlandırır." (ÖA, 1)

- "Bilgi okuryazarlığı, ev inşa etmek gibidir. Çünkü bilgi să̆lam olmazsa tıpkı ev gibi üstüne hiçbir şey inşa edilemez." (ÖA, 22)

- "Bilgi okuryazarlığı, bir insanı tanımak gibidir. Çünkü bir insanı tanımak için onun her davranışını iyi okumak ve anlamak gerekir." (ÖA, 10)

- "Bilgi okuryazarlı̆̆l, su içmek gibidir. Çünkü su içmek insanın en önemli ihtiyacı olduğu gibi bilgiye ulaşmak ve öğrenmek de yaşam boyu süren ihtiyacıdır." (ÖA, 27)

- "Bilgi okuryazarlı̆̆ı, süzgeç gibidir. Çünkü öğrendiğimiz her bilgiyi kendi süzgecimizden geçiririz." (ÖA, 40)

- "Bilgi okuryazarlı̆̆l, yemek yemek gibidir. Çünkü yemek yedikçe nasıl ki büyüme ve gelişme hızlanıyorsa bilgiyi aldıkça da gelişirsin." (ÖA, 44)

- "Bilgi okuryazarlığı, kitap gibidir. Çünkü bilgi okuryazarlı̆̆ındaki zenginliğge benzer şekilde kitabın her kelimesinden de farklı bilgiler alırsınız." (ÖA,6)

- "Bilgi okuryazarlh̆̆g, örgü örmek gibidir. Çünkü doğru şiş, uygun ip ve örgü deseni bilmeden güzel bir sonuç alamayız." (ÖA, 2)

Tablo 6'da öğretmen adaylarının "medya okuryazarlığı" kategorisine yönelik metafor algılarının frekans dağılımı yer almaktadır.

Tablo 6. Öğretmen adaylarının "medya okuryazarlığı" kategorisine yönelik ürettikleri metaforlar

\begin{tabular}{|c|c|c|c|c|c|c|c|c|}
\hline \multirow{15}{*}{ 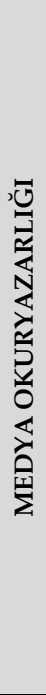 } & METAFOR & $f$ & \multirow{15}{*}{ 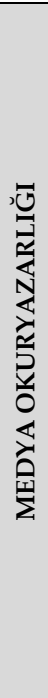 } & METAFOR & $f$ & \multirow{15}{*}{ 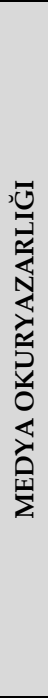 } & METAFOR & $f$ \\
\hline & Yapboz & 2 & & Miyop Gözlük & 1 & & Bitki Yetiştirmek & 1 \\
\hline & İzlediğin Filmi Anlamak & 1 & & Kıyafet Alan Bir Kadın & 1 & & Kitap Okumak & 1 \\
\hline & Fabl Okumak & 1 & & Dedektif & 1 & & Tarafsız Birey & 1 \\
\hline & Çizgi Film İzlemek & 1 & & Kar & 1 & & Meraklı Komşu & 1 \\
\hline & Araba Konvoyu & 1 & & Lunapark & 1 & & Taksimde Yürümek & 1 \\
\hline & $\begin{array}{c}\text { Alışveriş Merkezinde } \\
\text { Gezmek }\end{array}$ & 1 & & Sosyal Medya & 1 & & Sinir Hücreleri & 1 \\
\hline & $\begin{array}{l}\text { Her Yeni Durumda Bilgili } \\
\text { Olmak }\end{array}$ & 1 & & Çamaşır Yıkamak & 3 & & Magazin İzlemek & 1 \\
\hline & At Gözlüğü & 1 & & Ayna & 2 & & Bilgisayar Oyunu & 1 \\
\hline & Birine Liderlik Etmek & 1 & & Boya & 1 & & $\begin{array}{l}\text { Sanat Eseri } \\
\text { Yorumlamak }\end{array}$ & 1 \\
\hline & Yabanc1 Dil & 1 & & Filtre & 1 & & & \\
\hline & Karikatür & 1 & & Süzgeç & 5 & & & \\
\hline & Haber Bülteni & 1 & & $\begin{array}{c}\text { Rüzgârın Pencereye Çarparak Çıkardığı } \\
\text { Ses }\end{array}$ & 1 & & & \\
\hline & Telefonla Uğraşmak & 2 & & Bukalemun & 4 & & & \\
\hline & Uçağa Binmek & 1 & & Ev Eleştirmeni & 1 & & TOPLAM & 49 \\
\hline
\end{tabular}

Tablo 6'da öğretmen adaylarının "medya okuryazarlığı" kategorisine yönelik ürettikleri metaforlar frekans dağılımlarına göre incelendiğinde "süzgeç $(\mathrm{f}=5)$ " en çok tercih edilen metafordur. Bu metaforun ardından "bukalemun ( $\mathrm{f}=4)$ ", "çamaşır yıkamak ( $\mathrm{f}=3)^{\prime}$ ", "yapboz $(\mathrm{f}=2)$ ", "telefonla uğraşmak $(\mathrm{f}=2)$ " ve "ayna $(\mathrm{f}=2)$ " metaforları gelmektedir. Diğer metafor 
imgelerin frekans değerleri ise $1^{\prime}$ dir. Öğretmen adaylarının "medya okuryazarlığı" kategorisine ilişkin ifadelerden bazıları aşağıdaki şekildedir.

- “Medya okuryazarlığı, süzgeç gibidir. Çünkü medyadaki bilgileri olduğu şekliyle değil akıl süzgecimizden geçirerek okuruz." (ÖA, 2)

- "Medya okuryazarliğı, süzgeç gibidir. Çünkü süzgeçten geçen çay nasıl berraksa medyaya yansıyan haberleri de her yönüyle analiz ederek okuyabilmekte o kadar önemlidir." (ÖA, 31)

- "Medya okuryazarlığı, bukalemun gibidir. Çünkü medya yoluyla edinilen bilgiler farklı ortamlarda da işimize yarar." (ÖA,47)

- "Medya okuryazarlığı, çamaşır yıkamak gibidir. Çünkü aldığımız haberlerdeki kirlilikleri medya okuryazarlığı ile temizleriz." (ÖA, 35)

- "Medya okuryazarlığı, yapboz gibidir. Çünkü bütüne ulaşmak için parçaları iyi okumak gerekir." $(\ddot{O} A, 6)$

- "Medya okuryazarlığı, telefonla uğraşmak gibidir. Çünkü içerisinde çoğu sosyal macerayı barındırır." (ÖA, 29)

- "Medya okuryazarlığı, ayna gibidir. Çünkü bilgileri ayna gibi olduğu şekliyle yansıtmak noktasinda önemli rol oynar." (ÖA, 40)

- "Medya okuryazarlı̆̆ı, fabl okumak gibidir. Çünkü herkes okur fakat bazıları sadece gülüp geçerken bazıları hayata dair doğru çıkarımlar yapabilir." (ÖA, 3)

Tablo 7'de öğretmen adaylarının “BİT (bilgi, iletişim ve teknoloji) okuryazarlığı" kategorisine yönelik metafor algılarının frekans dağılımı yer almaktadır.

Tablo 7. Öğretmen adaylarının “BİT (bilgi, iletişim ve teknoloji) okuryazarlığı” kategorisine yönelik ürettikleri metaforlar

\begin{tabular}{|c|c|c|c|c|c|c|c|c|}
\hline \multirow{16}{*}{ 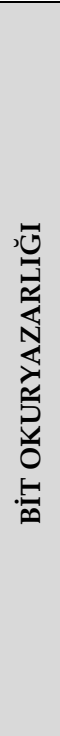 } & METAFOR & $f$ & \multirow{16}{*}{ 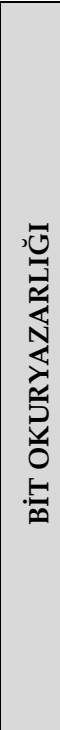 } & METAFOR & $f$ & \multirow{16}{*}{ 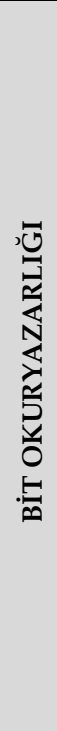 } & METAFOR & $\bar{f}$ \\
\hline & DNA & 1 & & Pulluk & 1 & & Okuma-Yazma Bilmek & 1 \\
\hline & Doğru Otobüsü Bulmak & 1 & & Bilgisayar Seçmek & 1 & & Adaptör & 1 \\
\hline & $\begin{array}{c}\text { Navigayonla Yol } \\
\text { Bulmak }\end{array}$ & 1 & & Çiçeğin Açması & 1 & & Yapboz & 1 \\
\hline & Büyümek & 1 & & Güneş & 1 & & Alışveriş Yapmak & 1 \\
\hline & Bilim & 1 & & Bilgisayar & 1 & & Elma & 1 \\
\hline & Yemek Yapmak & 1 & & Bukalemun & 2 & & Kahve İçmek & 1 \\
\hline & Antika Bulmak & 1 & & Adım & 1 & & 3 Bilinmeyenli Denklem & 1 \\
\hline & Merak & 1 & & Vida & 1 & & Kültür & 1 \\
\hline & Ağacın Kökleri & 1 & & Anne-Çocuk İlişkisi & 1 & & Takip & 1 \\
\hline & Kitap Okumak & 2 & & $\begin{array}{l}\text { Ateşi Bulup Yemek } \\
\text { Yapmayı Öğrenmek }\end{array}$ & 1 & & Ayna & 1 \\
\hline & $\begin{array}{c}\text { Yabancı Bir Ülkede } \\
\text { Olmak }\end{array}$ & 1 & & İplik Çekmek & 1 & & $\begin{array}{l}\text { Yeni Çağa Ayak } \\
\text { Uydurmak }\end{array}$ & 1 \\
\hline & Madde Döngüleri & 2 & & Yürümek & 2 & & Çay İçmek & 1 \\
\hline & Telefon & 2 & & Dil Öğrenmek & 2 & & Kiyafet Alıp Giymek & 1 \\
\hline & Teknolojik Aletler & 1 & & Kuyu & 1 & & & \\
\hline & Ahtapot & 1 & & Pencere & 1 & & TOPLAM & 49 \\
\hline
\end{tabular}

Tablo 7' de öğretmen adaylarının “BİT (bilgi, iletişim ve teknoloji) okuryazarlığ1” kategorisine yönelik ürettikleri metaforlar frekans dağılımlarına göre incelendiğinde "kitap okumak $(\mathfrak{f}=2)$ ", "madde döngüleri $(\mathrm{f}=2)$ ", "telefon $(\mathrm{f}=2)$ ", "bukalemun $(\mathrm{f}=2)$ ", "yürümek $(\mathrm{f}=2)$ " ve "dil öğrenmek $(\mathfrak{f}=2)$ " en çok tercih edilen metaforlardır. Diğer metafor imgelerin frekans değerleri 
ise 1' dir. Öğretmen adaylarının "BİT (bilgi, iletişim ve teknoloji) okuryazarlığı" kategorisine ilişkin ifadelerden bazıları aşağıdaki şekildedir.

- "BİT okuryazarlığı, kitap okumak gibidir. Çünkü hem bireyin iletişim kurmasını hem de elinde olan her şeyi daha iyi anlayabilmesini să̆lar." (ÖA, 10)

- "BİT okuryazarlı̆̆ı, madde döngüleri gibidir. Çünkü birbirleriyle etkileşim içerisindedir." (ÖA, 32)

- "BİT okuryazarlığı, telefon gibidir. Çünkü içerisinde bilgi, iletişim ve teknoloji var." (ÖA, 37)

- "BİT okuryazarlı̆̆ı̆, bukalemun gibidir. Çünkü bilgi, iletişim ve teknoloji üçlüsü ile her şeye ayak uydurulur." (ÖA, 22)

- "BİT okuryazarlı̆̆g, yürümek gibidir. Çünkü yanlış tarafa yürürsen yanlış yere gidersin. Bilgi, iletişim ve teknolojiyi kullanarak hedefe doğru bir şekilde yürüyebiliriz." (ÖA, 40)

- "BİT okuryazarlı̆̆l, dil öğrenmek gibidir. Çünkü kelimelerin anlamlarını, söylenişlerini okumak ve öğrenmek dil için ne kadar önemliyse bilgi, iletişim ve teknoloji okur yazar olmak o kadar önemlidir." $(\ddot{O A}, 29)$

- "BİT okuryazarliğı, çiçeğin açması gibidir. Çünkü ilk başta bilgi ile tohum ekilir sonra iletişim ve teknoloji ile o tohum filizlenir." (ÖA, 18)

- "BİT okuryazarlı̆̆ı, yapboz gibidir. Çünkü bu üç okuryazarlık bir bütün gibidir parçalar birleştiğinde anlam kazanır." (ÖA, 38)

\section{Üçüncü Alt Probleme İlişkin Bulgular}

Araştırmanın üçüncü alt problemi 21. yy. "Yaşam ve kariyer becerileri" temel beceri alanı kapsamında; öğretmen adaylarının "esneklik ve uyarlanabilirlik", "girişim ve kendine yön verme becerisi", "sosyal ve kültürler arası beceriler", "verimlilik ve hesap verebilirlik", "liderlik ve sorumluluk" alt kategorilerinde ürettikleri metaforlar nelerdir? şeklindedir.

Tablo 8' de öğretmen adaylarının "esneklik ve uyarlanabilirlik", kategorisine yönelik metafor algılarının frekans dağılımı yer almaktadır.

Tablo 8. Öğretmen adaylarının "esneklik ve uyarlanabilirlik" kategorisine yönelik ürettikleri metaforlar

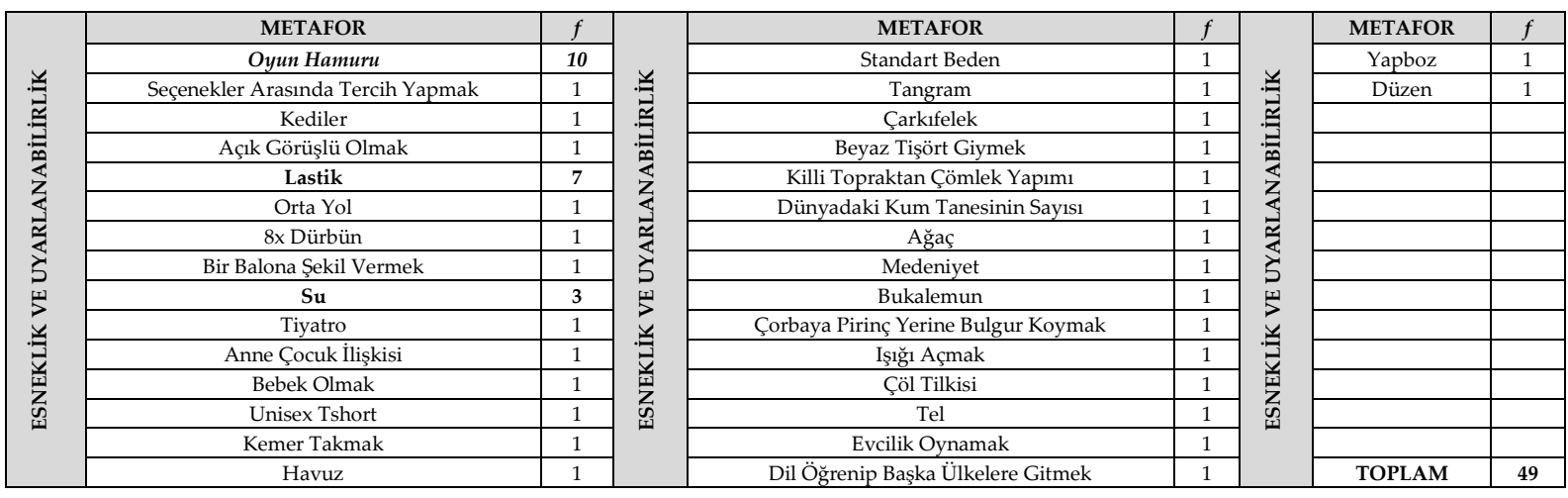

Tablo 8' de öğretmen adaylarının "esneklik ve uyarlanabilirlik" kategorisine yönelik ürettikleri metaforlar frekans dağılımlarına göre incelendiğinde "oyun hamuru ( $\mathrm{f}=10$ )" en çok tercih edilen metafordur. Bu metaforun ardından ikinci sırada "lastik ( $\mathrm{f}=7$ )" metaforu gelmektedir. 
Ayrıca, "su ( $f=3)$ " metaforu da üretilmiştir. Diğer metafor imgelerin frekans değerleri ise 1' dir. Öğretmen adaylarının "esneklik ve uyarlanabilirlik" kategorisine ilişkin ifadelerden bazıları aşağıdaki şekildedir.

- "Esneklik ve uyarlanabilirlik, oyun hamuru gibidir. Çünkü istediğimiz şekli verebiliriz." (ÖA, 1)

- "Esneklik ve uyarlanabilirlik, oyun hamuru gibidir. Çünkü belli bir şekle bağh kalmadan isteğince şekillendirebilirsin." (ÖA, 6)

- "Esneklik ve uyarlanabilirlik, oyun hamuru gibidir. Çünkü hamuru istediğin şekle getirip uyarlayabilirsin." (ÖA, 32)

- "Esneklik ve uyarlanabilirlik, lastik gibidir. Çünkü lastikte herhangi bir şekle gelebilmek ve uyarlanabilmek için farklı bir şekilde esneme özelliği vardır." (ÖA, 47)

- "Esneklik ve uyarlanabilirlik, lastik gibidir. Çünkü lastiğgi takacağımız yere göre ayarlayabiliyoruz bakış açısını da böyle esnetebiliriz." (ÖA, 37)

- "Esneklik ve uyarlanabilirlik, su gibidir. Çünkü bulunduğu kabın şeklini alır ve ortama uyum să̆lar." (ÖA, 40)

- "Esneklik ve uyarlanabilirlik, su gibidir. Çünkü bir şekilde akıp yolunu bulur." (ÖA, 11)

- "Esneklik ve uyarlanabilirlik, bukalemun gibidir. Çünkü bukalemun gibi bu beceriye sahip insanlar da her girdiği ortamın rengine uyum sağlayabiliyor." (ÖA, 33)

Tablo 9'da öğretmen adaylarının "girişim ve kendine yön verme becerisi" kategorisine yönelik metafor algılarının frekans dağılımı yer almaktadır.

Tablo 9. Öğretmen adaylarının "girişim ve kendine yön verme becerisi" kategorisine yönelik ürettikleri metaforlar

\begin{tabular}{|c|c|c|c|c|c|c|c|c|}
\hline \multirow{16}{*}{ 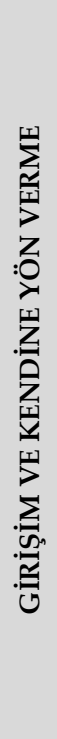 } & METAFOR & $f$ & \multirow{16}{*}{ 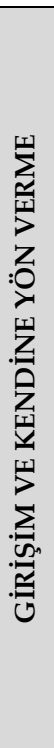 } & METAFOR & $f$ & \multirow{16}{*}{ 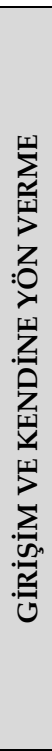 } & METAFOR & $f$ \\
\hline & Bilgisayar Oyunu & 1 & & Bisiklet & 1 & & Spor Yapmak & 1 \\
\hline & Su Tesisatı & 2 & & Yapboz Parçası & 1 & & Labirent & 2 \\
\hline & Akarsu & 2 & & İlerigörüşlük & 1 & & $\begin{array}{l}\text { Navigasyon } \\
\text { Kullanmak }\end{array}$ & 1 \\
\hline & Araba Kullanmak & 5 & & Ders Anlatmak & 1 & & Bitki Kökü & 1 \\
\hline & Aynaya Bakmak & 1 & & Bisiklet Sürmek & 1 & & Yemek Yapmak & 1 \\
\hline & İzcilik & 1 & & $\begin{array}{c}\text { Okyanus Ortasında Yönün } \\
\text { Kaybetmiş Gemi }\end{array}$ & 1 & & Adres Sormak & 1 \\
\hline & Cesaret & 1 & & Yaşamak & 1 & & 400m Engelli Koşu & 1 \\
\hline & Risk Almak & 1 & & Yağmur & 1 & & Gemi & 1 \\
\hline & Ak1l Yönetmek & 1 & & Yeni Dükkân Açmak & 1 & & Çilek & 1 \\
\hline & Aşk Ateşi & 1 & & Lamba & 1 & & Yazı Yazmak & 1 \\
\hline & Okyanusa Atlamak & 1 & & $\mathrm{Su}$ & 1 & & & \\
\hline & Gemi Yelkeni & 1 & & Yüzmek & 1 & & & \\
\hline & Tren Rayındaki Makas & 1 & & Tavuk & 1 & & & \\
\hline & Pusula & 2 & & Yeni Bir İşe Başvurmak & 2 & & & \\
\hline & Yürek & 1 & & $\begin{array}{c}\text { Saatteki Akrep ve Yelkovanın } \\
\text { Hareketi }\end{array}$ & 1 & & TOPLAM & 49 \\
\hline
\end{tabular}

Tablo 9' da öğretmen adaylarının "girişim ve kendine yön verme becerisi" kategorisine yönelik ürettikleri metaforlar frekans dağılımlarına göre incelendiğinde "araba kullanmak ( $\mathrm{f}=5)^{\text {" en }}$ çok tercih edilen metafordur. Bu metaforun ardından ikinci sırada "su tesisatı $(\mathrm{f}=2)$ ", "akarsu $(\mathrm{f}=2)$ ", "pusula $(\mathrm{f}=2)$ ", "yeni bir işe başvurmak $(\mathrm{f}=2)$ " ve "labirent $(\mathrm{f}=2)$ " metaforları gelmektedir. Diğer metafor imgelerin frekans değerleri ise 1' dir. Öğretmen adaylarının 
"girişim ve kendine yön verme becerisi" kategorisine ilişkin ifadelerden bazıları aşağıdaki şekildedir.

- "Girişim ve kendine yön verme becerisi, araba kullanmak gibidir. Çünkü direksiyonu nereye çevirirsen o yöne gidersin." (ÖA, 32)

- "Girişim ve kendine yön verme becerisi, araba kullanmak gibidir. Çünkü ne kadar sakin olsak da bazı kritik yerlerde cesur ve doğru hareket edebilmeliyiz." (ÖA, 11)

- "Girişim ve kendine yön verme becerisi, araba kullanmak gibidir. Çünkü hakimiyet bizdedir istediğimiz yola girebiliriz." (ÖA,4)

- "Girişim ve kendine yön verme becerisi, su tesisatı gibidir. Çünkü boruları doğru döşeyip onlar doğru yönlendirmezsen tüm tesisat çöker." (ÖA, 2)

- "Girişim ve kendine yön verme becerisi, akarsu gibidir. Çünkü bir şeyler yapmaya başladığınızda gerisi kendiliğinden akıp gider." (ÖA, 3)

- "Girişim ve kendine yön verme becerisi, pusula gibidir. Çünkü kendimiz için en iyi yolu yine kendimiz seçeriz." (ÖA, 18)

- "Girişim ve kendine yön verme becerisi, yeni bir işe başvurmak gibidir. Çünkü kendimizi daha iyi geliştirebileceŏimiz işe başvurup hayatımıza yön veririz." (ÖA, 34)

- “Girişim ve kendine yön verme becerisi, labirent gibidir. Çünkü hayat labirenti içerisindeki riskler karşısında kendimize doğru yön vererek labirentin çıkışına doğru gideriz." (ÖA, 38)

- "Girişim ve kendine yön verme becerisi, izcilik gibidir. Çünkü tıpkı izcilikte olduğu gibi girişimcilikte de izleri doğru takip ederseniz sonuca ulaşırsınız." (ÖA, 7)

Tablo 10'da öğretmen adaylarının "sosyal ve kültürler arası beceriler" kategorisine yönelik metafor algılarının frekans dağılımı yer almaktadır.

Tablo 10. Öğretmen adaylarının "sosyal ve kültürler arası beceriler" kategorisine yönelik ürettikleri metaforlar

\begin{tabular}{|c|c|c|c|c|c|c|c|c|}
\hline \multirow{16}{*}{ 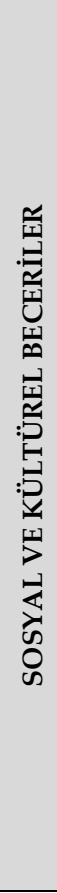 } & METAFOR & $f$ & \multirow{16}{*}{ 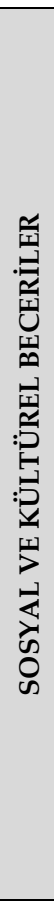 } & METAFOR & $f$ & \multirow{16}{*}{ 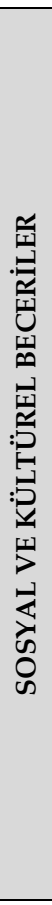 } & METAFOR & $f$ \\
\hline & Gökkuşağ1 & 1 & & Halay Çekmek & 1 & & $\begin{array}{c}\text { Başka Bir Şehirde } \\
\text { Yaşamak }\end{array}$ & 1 \\
\hline & $\begin{array}{c}\text { Bir Müzisyenin Kitap } \\
\text { Yazması }\end{array}$ & 1 & & Halat & 1 & & $\begin{array}{l}\text { Başka Şehirlerde Aynı } \\
\text { Yemeği Yapmak }\end{array}$ & 1 \\
\hline & $\begin{array}{l}\text { Anteplinin Sebze } \\
\text { Yemeği Yapması }\end{array}$ & 1 & & İnstagram & 1 & & Ayna & 1 \\
\hline & Gezmek & 6 & & Zekâ Küpü & 1 & & Alışveriş & 1 \\
\hline & Spor Yapmak & 2 & & Halk Oyunları & 2 & & Doğa & 1 \\
\hline & $\begin{array}{l}\text { Çiçek Bahçesine } \\
\text { Girmek }\end{array}$ & 1 & & Okuldaki Sınıf & 1 & & Çorap Seçmek & 1 \\
\hline & Açık Büfe Kahvaltı & 1 & & İp & 1 & & Oyun Oynamak & 1 \\
\hline & Yeni Ufuklar & 1 & & Yapboz & 2 & & Araba Kullanmak & 1 \\
\hline & İngiliz Anahtarı & 1 & & $\begin{array}{c}23 \text { Nisan'a Hazırlanan } \\
\text { Çocuk }\end{array}$ & 1 & & Halı & 1 \\
\hline & Müzik & 2 & & Tatlı Yemek & 1 & & Sazan Sarmalı & 1 \\
\hline & Festival & 1 & & Dans Etmek & 1 & & & \\
\hline & Aktif Olmak & 1 & & $\begin{array}{c}\text { Denemediğin Bir Yemek } \\
\text { Yapmak }\end{array}$ & 1 & & & \\
\hline & Tokalaşmak & 1 & & Deniz & 1 & & & \\
\hline & Dizüstü Bilgisayar & 1 & & Elbise & 1 & & & \\
\hline & $\begin{array}{l}\text { Her Mevsime Uygun } \\
\text { Kıyafet Seçmek }\end{array}$ & 1 & & $\mathrm{Su}$ & 1 & & TOPLAM & 49 \\
\hline
\end{tabular}


Tablo 10'da öğretmen adaylarının "sosyal ve kültürler arası beceriler" kategorisine yönelik ürettikleri metaforlar frekans dağılımlarına göre incelendiğinde "gezmek ( $f=6)$ " en çok tercih edilen metafordur. Bu metaforun ardından ikinci sirada "spor yapmak $(\mathrm{f}=2)$ ", "müzik dinlemek $(\mathrm{f}=2)$ ", "halk oyunları $(\mathrm{f}=2)$ " ve "yapboz $(\mathrm{f}=2)$ " metaforları gelmektedir. Diğer metafor imgelerin frekans değerleri ise 1' dir. Öğretmen adaylarının "sosyal ve kültürler arası beceriler" kategorisine ilişkin ifadelerden bazıları aşağıdaki şekildedir.

- "Sosyal ve kültürler arası beceriler, gezmek gibidir. Çünkü bir yeri gezerken yeni şeyler öğrenir ve sosyal / kültürel becerilerimizi geliştiririz" (ÖA, 37)

- "Sosyal ve kültürler arası beceriler, gezmek gibidir. Çünkü gezdikçe kültürler arası beceriler artar." (ÖA, 45)

- "Sosyal ve kültürler arası beceriler, gezmek gibidir. Çünkü gezdikçe tanı öğrenir ve gelişirsiniz." $(\ddot{O} A, 4)$

- "Sosyal ve kültürler arası beceriler, spor yapmak gibidir. Çünkü spor, kültürler ve insanların sosyalleşmesi arasındaki köprüdür." (ÖA,48)

- "Sosyal ve kültürler arası beceriler, müzik gibidir. Çünkü müzik hem farklı kültürleri birleştirir hem de insant geliştirir." (ÖA, 10)

- "Sosyal ve kültürler arası beceriler, halk oyunları gibidir. Çünkü halk oyununu farklı yörelerden olan bireyler bile oynayabilirler." (ÖA, 36)

- "Sosyal ve kültürler arası beceriler, yapboz gibidir. Çünkü farklı parçalar birleşerek bir bütünü oluşturur." (ÖA, 25)

- "Sosyal ve kültürler arası beceriler, halay çekmek gibidir. Çünkü halayda herkesin eli birleşir ve uyumlu bir oyun oynanır, kültürlerin birleşiminde de uyumlu bir mozaik oluşur." (ÖA, 18)

Tablo 11'de öğretmen adaylarının "verimlilik ve hesap verebilirlik" kategorisine yönelik metafor algılarının frekans dağılımı yer almaktadır.

Tablo 11. Öğretmen adaylarının "verimlilik ve hesap verebilirlik" kategorisine yönelik ürettikleri metaforlar

\begin{tabular}{|c|c|c|c|c|c|c|c|c|}
\hline \multirow{16}{*}{ 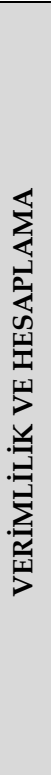 } & METAFOR & $f$ & \multirow{16}{*}{ 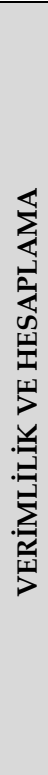 } & METAFOR & $f$ & \multirow{16}{*}{ 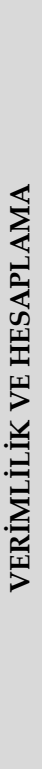 } & METAFOR & $f$ \\
\hline & Toprak & 2 & & Z Raporu & 1 & & Ders Çalışmak & 2 \\
\hline & Tarlayı Gübrelemek & 1 & & Çok Yemek veya Az Yemek & 1 & & Yıllık Ders Planı & 1 \\
\hline & $\begin{array}{l}\text { Abimle Benim Ders } \\
\text { Çalışmam }\end{array}$ & 1 & & Para & 1 & & Grup Başkanı & 1 \\
\hline & Aile Bütçesi & 1 & & Çalışmak & 1 & & Oyun Oynamak & 1 \\
\hline & Müşteri Hizmetleri & 1 & & Çay Tarlası & 1 & & Beyaz Eşya Kullanmak & 1 \\
\hline & Alışveriş Yapmak & 1 & & Öğrenci & 1 & & Mertlik & 1 \\
\hline & Çiftçilik & 1 & & Kot Ceket & 1 & & Çiçek Sulamak & 1 \\
\hline & İç Huzuru & 1 & & $\begin{array}{l}\text { Eşli Okey Oynandığında Düzgün } \\
\text { Oynamak }\end{array}$ & 1 & & Etki-Tepki Yasası & 1 \\
\hline & Keçi Sütü & 1 & & Kum Saati & 1 & & Tasarruflu Ampul & 1 \\
\hline & Bitki Yetiştirmek & 7 & & Delik Kova & 1 & & & \\
\hline & Yazı Yazmak & 1 & & Amel Defteri & 1 & & & \\
\hline & $\begin{array}{c}\text { Ailedeki En Büyük } \\
\text { Çocuk }\end{array}$ & 1 & & Bilgisayar Oyunu & 2 & & & \\
\hline & Patron Çalışan İlişkisi & 2 & & Ayna & 1 & & & \\
\hline & Saate Bakmak & 1 & & Öğretmen & 1 & & & \\
\hline & $\begin{array}{l}\text { Hafizalı Hesap } \\
\text { Makinası }\end{array}$ & 1 & & Muhasebe Tutmak & 1 & & TOPLAM & 49 \\
\hline
\end{tabular}


Tablo 11'de öğretmen adaylarının "verimlilik ve hesap verebilirlik" kategorisine yönelik ürettikleri metaforlar frekans dağılımlarına göre incelendiğinde "bitki yetiştirmek (f=7)" en çok tercih edilen metafordur. Bu metaforun ardından ikinci sırada "toprak $(\mathrm{f}=2)$ ", "patron çalışan ilişkisi $(\mathrm{f}=2)$ ", "bilgisayar oyunu $(\mathrm{f}=2)$ " ve ders çalışmak $(\mathrm{f}=2)$ " metaforları gelmektedir. Diğer metafor imgelerin frekans değerleri ise 1' dir. Öğretmen adaylarının "verimlilik ve hesap verebilirlik" kategorisine ilişkin ifadelerden bazıları aşağıdaki şekildedir.

- "Verimlilik ve hesap verebilirlik, bitki yetiştirmek gibidir. Çünkü bir tohum ekersin birçok meyvesini yersin." (ÖA, 25)

- "Verimlilik ve hesap verebilirlik, bitki yetiştirmek gibidir. Çünkü ne kadar iyi bakarsan o oranda verim elde edersin." (ÖA, 30)

- "Verimlilik ve hesap verebilirlik, bitki yetiştirmek gibidir. Çünkü tohuma nasıl bakarsan o kadar çok olumlu dönüt ve verim alırsın." (ÖA, 12)

- "Verimlilik ve hesap verebilirlik, toprak gibidir. Çünkü toprağa gereken önem ve özeni gösterirsen sana da dönüt verir." (ÖA, 29)

- "Verimlilik ve hesap verebilirlik, patron çalışan ilişkisi gibidir. Çünkü çalışan, verimliliğine göre patrona hesap verir." (ÖA, 26)

- "Verimlilik ve hesap verebilirlik, bilgisayar oyunu gibidir. Çünkü takımına katkı sağladığııda verimli olursun hata yaptığında açıklamasını yapmak zorundasındır." (ÖA, 47)

- "Verimlilik ve hesap verebilirlik, ders çalışmak gibidir. Çünkü çalışıp konuya hâkim oldukça özgüven ve verim doğru orantılı bir şekilde artar." (ÖA,36)

- "Verimlilik ve hesap verebilirlik, grup başkan gibidir. Çünkü başkan yönettiklerine her şeyin hesabını verirse verimlilik gerçekleşir." (ÖA,36)

Tablo 12'de öğretmen adaylarının "liderlik ve sorumluluk" kategorisine yönelik metafor algılarının frekans dağılımı yer almaktadır.

Tablo 12. Öğretmen adaylarının "liderlik ve sorumluluk" kategorisine yönelik ürettikleri metaforlar

\begin{tabular}{|c|c|c|c|c|c|c|c|c|}
\hline \multirow{16}{*}{ 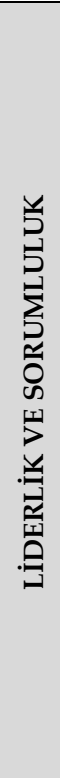 } & METAFOR & $f$ & \multirow{16}{*}{ 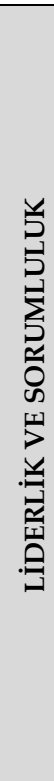 } & METAFOR & $f$ & \multirow{16}{*}{ 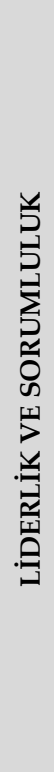 } & METAFOR & $f$ \\
\hline & Satrançtaki Şah & 1 & & Patron & 1 & & Şoför & 1 \\
\hline & $\begin{array}{c}\text { Araba } \\
\text { Kullanmak }\end{array}$ & 2 & & Fotokopi Çekmek & 1 & & $\begin{array}{c}\text { Suyun Kaba Göre Şekil } \\
\text { Alması }\end{array}$ & 1 \\
\hline & Anne Olmak & 3 & & Başkanlık & 1 & & Gemi Kaptanı & 1 \\
\hline & Baba Olmak & 3 & & Elmas & 1 & & Anne Kuş & 1 \\
\hline & Diyet Yapmak & 1 & & Dambil & 1 & & Stannis Karakteri & 1 \\
\hline & Denizi İzlemek & 1 & & Öğretmenlik & 1 & & Restoran Şefi Olmak & 1 \\
\hline & $\begin{array}{c}\text { Konuşma } \\
\text { Yapmak }\end{array}$ & 1 & & İlkokulda Sınıf Başkanı Olmak & 1 & & Gezi Rehberi Olmak & 1 \\
\hline & Gereklilik & 1 & & Bina Temeli & 1 & & Kiliç & 1 \\
\hline & $\begin{array}{l}\text { Gömleğin } \\
\text { Düğmeleri }\end{array}$ & 2 & & Beyin & 1 & & Kedi Beslemek & 1 \\
\hline & $\begin{array}{l}\text { Batonu Hareket } \\
\text { Ettirmek }\end{array}$ & 1 & & Her Gün Uyanacağınızı Bilmek & 1 & & Evin Direği Olmak & 1 \\
\hline & Treyler Sürmek & 1 & & Kurt Sürüsü & 1 & & Sabir & 1 \\
\hline & Devlet & 1 & & Yağmur & 1 & & İş Yeri Çalıştırmak & 1 \\
\hline & Cumhurbaşkanı & 1 & & Kalem & 1 & & Yağmur Ormanları & 1 \\
\hline & İşaret Fişeği & 1 & & Sınıf Yönetmek & 1 & & & \\
\hline & Cesaret & 1 & & Aslan & 1 & & TOPLAM & 49 \\
\hline
\end{tabular}


Tablo 12'de öğretmen adaylarının "liderlik ve sorumluluk" kategorisine yönelik ürettikleri metaforlar frekans dağılımlarına göre incelendiğinde "anne olmak $(\mathrm{f}=3)^{\prime}$ " ve "baba olmak $(\mathrm{f}=3)^{\prime}$ " en çok tercih edilen metafordur. Bu metaforun ardından ikinci sırada "araba kullanmak $(\mathrm{f}=2)$ " ve "gömleğin düğmeleri $(\mathrm{f}=2)$ " metaforları gelmektedir. Diğer metafor imgelerin frekans değerleri ise 1' dir. Öğretmen adaylarının "liderlik ve sorumluluk" kategorisine ilişkin ifadelerden bazıları aşağıdaki şekildedir.

- "Liderlik ve sorumluluk, anne olmak gibidir. Çünkü hem en iyi öncül hem de zamanın iş ve aileye en iyi ayırandır." (ÖA,3)

- "Liderlik ve sorumluluk, baba olmak gibidir. Çünkü baba olmak hem bir aileye lider olmak hem de o ailenin her şeyinden sorumlu olmaktır." (ÖA, 4)

- "Liderlik ve sorumluluk, anne olmak gibidir. Çünkü anne her işe koşuşturup her işi de kendi kontrolü altında tutmak ister." (ÖA, 29)

- "Liderlik ve sorumluluk, baba olmak gibidir. Çünkü bir baba nasıl evlatlarma karşı sorumluluk hissediyorsa lider kişi de yönettiği insanlara karşı o sorumluluğu hissetmelidir." (ÖA, 38)

- "Liderlik ve sorumluluk, araba kullanmak gibidir. Çünkü debriyaj, gaz, fren ayarını doğru yapmazsanız arabayı çalıştıramazsınız." (ÖA, 2)

- "Liderlik ve sorumluluk, gömleğin düğmeleri gibidir. Çünkü baştaki yanlış olursa devamı da öyle gelir." (ÖA, 9)

- "Liderlik ve sorumluluk, fotokopi çekmek gibidir. Çünkü sen nasıl olursan etrafindakilerde öyle olur, sen iyi olursan onları da iyi yönlendirirsin." (ÖA, 9)

- "Liderlik ve sorumluluk, satrançtaki şah gibidir. Çünkü sorumluluk ve lider yoksa diğgr taşlarm önemi yoktur." (ÖA, 1)

- "Liderlik ve sorumluluk, yağmur ormanları gibidir. Çünkü yağmur ormanları bütün dünyaya yetecek oksijeni barındırdığı için dünyanın lideridir ve bir lider özgür olmalıdır o ă̆açlarda özgürlü̈̆̈̈̈ temsil eder." (ÖA, 14)

- "Liderlik ve sorumluluk, şoför gibidir. Çünkü araçtaki diğer insanların hayatı onun elinde, onun liderliği ve sorumluluğundadır." (ÖA, 34)

\section{Tartışma, Sonuç ve Öneriler}

Bu çalışmada 21. yüzyıl becerileri kapsamında ilköğretim matematik öğretmeni adaylarının "öğrenme ve yenilik becerileri", "bilgi, medya ve teknoloji becerileri", "yaşam ve kariyer becerileri" olmak üzere üç temel beceri alanına yönelik metaforik algılarını ortaya koymak amaçlanmıştır. Bu amaç doğrultusunda her temel beceri alanının alt kategorilerinde öğretmen adaylarının üretmiş oldukları metaforlar tablolaştırılmıştır. Genel olarak öğretmen adaylarının üretmiş oldukları metaforlar frekans dağılımlarına göre incelendiğinde en çok "oyun hamuru" metaforunun kullanıldı̆̆ı görülmektedir. Bu metaforun ardından "lastik", "bitki yetiştirmek" ve "gezmek" metaforları da çoğunlukla tercih edilmiştir.

Çalışmada ilk olarak 21. yüzyıl “öğrenme ve yenilik becerileri” temel beceri alanı kapsamında; öğretmen adaylarının "eleştirel düşünme ve sorun çözme", "yaratıcılık ve yenilik", "iletişim ve iş birliği" alt kategorilerinde üretmiş oldukları metaforlar kategorize edilmiştir. Bu metaforların frekans dağılımlarına bakıldığında; eleştirel düşünme ve sorun çözme 
kategorisinde "düğüm çözmek", yaratıcıllk ve yenilik kategorisinde "yemek yapmak", iletişim ve iş birliği kategorisinde ise "köprü" en çok tercih edilen metaforlardır. Eleştirel düşünme ve sorun çözme kategorisinde yer alan "dügüum çözmek" metaforu ile sorunlara doğru açılardan eleştirel bakış açısıyla bakmanın çözüm aşamasında oldukça önemli ve sürdürülebilir olduğu aksi takdirde sorunun kördügüum olacağı ifade edilmektedir. Facione (2011) eleştirel düşünmeyi; yorumlama, analiz, değerlendirme, çıkarım, açıklama ve öz düzenleme şeklinde tanımlanmaktadır. Narin \& Aybek (2010) ise aklın sınırlarını genişletmenin ve sorunlara farklı bakış açısıyla çözümler üretebilmenin yolunun eleştirel yaklaşabilmekten geçtiğini ifade etmektedirler. Ayrıca, Aybek \& Yolcu (2018) "İlkokul ve ortaokullarda görevli öğretmenlerin eleştirel düşünmeye ilişkin farkındalıkları" isimli çalışmalarında eleştirel düşünmeye yönelik metaforları "çok yönlü ve boyutlu düşünme", "farklı bakış açlarından yararlanma", "sorgulama", "akıl yürütme ve muhakeme içerme", “olasılıkları birleştirme" ve "tarafsız olma" şeklinde kategorize etmişlerdir.

Yaratıcılık ve yenilik kategorisinde yer alan "yemek yapmak" metaforu ile yeniliklere açık olmak ve doğru malzemeleri kullanarak özgün ürünler ortaya koymanın önemi vurgulanmaktadır. İletişim ve iş birliği kategorisinde yer alan "köprü" metaforu da iki taraf arasında duygu ve düşüncelerin paylaşılarak bir bağ kurulması şeklinde tanımlanmıştır. Hatta doğru yapı kurulduğunda köprü nasıl yolları birbirine bağlıyorsa doğru iletişimin de insanları birbirine bağladığına ve başarılı sonuçlara ulaşılacağına vurgu yapılmıştır. Çırak Kurt \& Yıldırım (2020) "İlköğretim matematik öğretmenleri ile öğretmen adaylarının çeşitli kavramlara ilişkin metaforik algıları" isimli çalışmalarında yer alan "öğretmenlik" kavramına ilişkin metafor ve kategoriler tablosunda; "yemek yapma" metaforunu "özveri gösterme" ve "köprü" metaforunu da "kılavuz / yol gösterici olma" kategorisinde değerlendirmişlerdir.

Öğretmen adayları tarafından "öğrenme ve yenilik becerileri” temel beceri alanı kapsamında en çok tercih edilen bu metaforların kullanılması karşılaşılan problemlerde farklı bakış açıları ve çözüm yollarını üretmeye, doğru iletişimi kurmaya yönelik yaklaşım olarak 21. yüzyıl becerilerinin kazanımları açısından oldukça önemlidir. Jacobson Lundeberg (2016), iletişim becerilerinin insan ilişkilerinin gelişiminde oldukça önemli bir güce sahip olduğunu vurgularken iletişimin gerçek amacının bilgiyi bir kişiden diğerine başarılı bir şekilde aktarılması gerektiğini de ifade etmektedir. Ayrıca doğru iletişimin; eleştirel düşünme, problem çözme, stres yönetimi ve risk alma vb. gibi durumlarda süreci olumlu yönde etkilediğini de belirtmektedir. Semerci (2003) okullarda eleştirel düşünen, ihtiyaç duyduğu bilgilere ulaşabilen ve bilgi üreten bireyler yetiştirmek için öncelikle öğretmenlerin bu nitelikleri taşımasının önemine işaret etmektedir.

İkinci olarak "bilgi, medya ve teknoloji becerileri" temel beceri alanı kapsamında; öğretmen adaylarının "bilgi okuryazarlığı", "medya okuryazarlığı”, “BİT (bilgi, iletişim ve teknoloji) okuryazarlığı" alt kategorilerinde üretmiş oldukları metaforlar kategorize edilmiştir. Bu metaforların frekans dağılımlarına bakıldığında; bilgi okuryazarlığ1 kategorisinde "kütüphane", medya okuryazarlığ1 kategorisinde "süzgeç", BİT (bilgi, iletişim ve teknoloji) okuryazarlığı kategorisinde ise "kitap okumak", "madde döngüleri”, "telefon”, “bukalemun”, "yürümek" ve "dil öğrenmek" metaforları aynı frekans değerine sahip en çok tercih edilen metaforlardır. Bilgi okuryazarlığı kategorisinde yer alan "kütüphane" metaforu ile doğru bilgiye ulaşma noktasında bir zenginlik olduğu ve edinilen her bilginin kütüphanedeki yapılanma şeklinde insan beyninde depolandığ 1 ifade edilmektedir. Medya okuryazarlığ kategorisindeki "süzgeç" metaforu ile medyadaki bilgilerin olduğu şekliyle değil akıl 
süzgecinden geçirilerek okunması noktasında önemli rol oynadığı vurgulanmaktadır. BİT (bilgi, iletişim ve teknoloji) okuryazarlığı kategorisinde ise; "kitap okumak" metaforu ile insanın elindekilerini doğru okuyarak iyi bir iletişim ağı oluşturacağı, "madde döngüleri" metaforu ile bilgi-iletişim-teknolojinin birbirleriyle ilişkili ve etkileşim içinde olduğu ve döngüsel şekilde devam ettiği sürece olumlu dönütler alınacağı, "telefon" metaforu ile içerisinde bilgi-iletişim-teknolojiyi barındırdığı, "bukalemun” ile her ortamda kullanıldığı ve gelişmeleri takip etmeye olanak sağladığı, "yürümek" ile doğru yönü bulmak için gerçekleştirilen rutin bir eylem, "dil öğrenmek" ile kelimelerin anlamlarını, söylenişlerini doğru olarak öğrenmek ve okumak nasıl ki doğru sonuca ulaştırıyorsa bilgi-iletişim-teknoloji kavramlarının da doğru öğrenilmesinin doğru becerilerin kazanılmasına kapı açacağı ifade edilmektedir.

Küçük \& Demir (2009) okuryazarlık kavramını; öğrencinin yazılı kaynakları bulma, kullanma, kabul etme ve değerlendirme adımlarını kullanarak bilgi ve potansiyelini geliştirip topluma daha etkili bir şekilde katılma ve katkı sağlama şeklinde tanımlamaktadır. Bu bağlamda öğretmen adaylarının "bilgi, medya ve teknoloji becerileri" temel beceri alanı kapsamında yer alan alt kategorilere göre üretmiş oldukları metaforların okuryazarlık kavramı ile örtüştüğü söylenebilir.

Üçüncü olarak "yaşam ve kariyer becerileri" temel beceri alanı kapsamında; öğretmen adaylarının "esneklik ve uyarlanabilirlik", "girişim ve kendine yön verme becerisi", "sosyal ve kültürler arası beceriler", "verimlilik ve hesap verebilirlik", "liderlik ve sorumluluk" alt kategorilerinde üretmiş oldukları metaforlar kategorize edilmiştir. Bu metaforların frekans dağılımlarına bakıldığında; esneklik ve uyarlanabilirlik kategorisinde "oyun hamuru", girişim ve kendine yön verme becerisi kategorisinde "araba kullanmak", sosyal ve kültürler arası beceriler kategorisinde "gezmek", verimlilik ve hesap verebilirlik kategorisinde "bitki yetiştirmek", liderlik ve sorumluluk kategorisinde ise "anne olmak" ve "baba olmak" metaforları aynı frekans değerine sahip en çok tercih edilen metaforlardır. Esneklik ve uyarlanabilirlik kategorisinde yer alan "oyun hamuru" metaforu ile belli bir şekle bağlı kalmadan değişik uygulamalar ile uygun ortamlara uyarlanabilirlik ifade edilmektedir. Girişim ve kendine yön verme becerisi kategorisindeki "araba kullanmak" metaforu ile kontrolün bireyde olduğu ve istediği yöne gitme noktasında kendisine yön verebildiği vurgulanmaktadır. Sosyal ve kültürler arası beceriler kategorisinde yer alan "gezmek" metaforu ile gezdikçe yeni şeylerin öğrenildiği ve kültürler arası becerilerin arttı̆̆ ön plana çıkarılmıştır. Verimlilik ve hesap verebilirlik kategorisindeki "bitki yetiştirmek" metaforu verim ve sonucunda olumlu dönüt almak şeklinde kullanılmıştır. Liderlik ve sorumluluk kategorisindeki "anne olmak" ve "baba olmak" metaforları ile de sorumluluk alan, kontrol altında tutmaya çalışan, söz sahibi ve fedakâr ifadelerine vurgu yapılmıştır.

Genel olarak öğretmen adaylarının üretmiş oldukları metaforlar incelendiğinde, 21. yüzyıl temel beceri alanlarının içeriklerine işaret eden metaforlar kullandıkları görülmektedir. Levine (2005) metaforların bireylerin bakış açılarını yansıtma işlevinin altında; geçmiş yaşantılar, bugünkü fikirler, geleceğe ait umut ve hayaller yattığına işaret etmektedir. Bu açıdan bakıldığında geleceğin öğrencisine öğretmenlik yapacak öğretmen adaylarının eğitiminde eleştirel ve yaratıcı düşünme, karar verme, sorun çözme, iş birliği ve iletişim becerilerinin geliştirilmesi oldukça önemlidir. Bu becerilerin geliştirilmesinde ezber bilgiler, geleneksel dersler ve öğrenmenin sınıf içine hapsedildiği ortamlar yerine öğrencilerin aktif olduğu, öğrenme grupları ile projeler yürüttüğü, araştırma ve tartışma etkinliklerinin ön planda 
olduğu eğitim süreçleri planlanmalıdır. Bunun yanında bilgi teknolojilerinin sürece entegre edildiği ve öğrenme kaynaklarının yerel ve evrensel bağlamda çeşitlendiği ortamlar oluşturulmalıdır. $\mathrm{Bu}$ amaç doğrultusunda; geleceğin öğretmenini yetiştirmek için programlarda öğrenmeyi ön planda tutan, bilimsel araştırma, uygulama ve sorun çözme odaklı temel bir anlayışla öğrenme liderliği yapabilecek öğretmenler yetiştirmek gerekmektedir (Yıldırım, 2018).

Ayrıca, ilköğretimden yükseköğretime kadar öğrencilerin yaşamlarına ve kariyerlerine dair gelişimlerini etkileyecek olan 21. yüzyıl becerilerinin öğretmenlerin sorumluluğunda olduğu da bir gerçektir (Anagün \& diğ., 2016). Bu açıdan bu bireyleri yetiştirecek öğretmenlerin de yeniliklere açık, farklı bakış açılarını dikkate alan, düşünen ve sorgulayan olması beklenmektedir. Millî Eğitim Bakanlığ1 2017-2023 Öğretmen Strateji Belgesi'nde de bir toplumun inşasında en önemli görevin öğretmenlere düştüğü ve eğitim sistemlerinin temel amacının; "topluma faydalı, toplumsal değerleri gözeten, etkili iletişim becerilerini edinmiş, değişime uyum sağlayabilen, öğrenme kaynaklarına erişme ve bunlardan etkin bir şekilde yararlanma becerilerini kazanmış, bilgi iletişim teknolojilerini verimli kullanabilen, kendisiyle ve toplumla barışık, inisiyatif alan, araştıran, sorgulayan ve eleştirel düşünme becerilerine sahip özgür bireyler yetiştirebilmek" olduğunu vurgulanmaktadır (MEB, 2017). Bu bağlamda özellikle öğretmen yetiştiren eğitim fakültelerinin geleceğin mimarı olan öğretmen adaylarına bu beceri ve yeterlikleri kazandırmaları oldukça önemlidir (Orhan Göksun, 2016). Bu becerileri kazandırma noktasında, öğretmen adaylarının eğitim süreçlerinde sahip oldukları zihinsel imgeleri açığa çıkararak zihinlerinde oluşturdukları şemaları anlamaları ve ihtiyaç halinde yeniden yapılandırmaları noktasında metaforlar pedagojik bir araç olarak kullanılmalıdır (Saban, 2008).

$\mathrm{Bu}$ çalışmada eğitim fakültesi ilköğretim matematik öğretmenliği bölümü öğretmen adaylarının görüşleri alınmıştır. Yapılacak çalışmalarda farklı eğitim fakülteleri ve bölümlerinde öğrenim gören öğretmen adaylarınınn 21. yüzyıl becerileri kapsamında; "öğrenme ve yenilik becerileri", "bilgi, medya ve teknoloji becerileri", "yaşam ve kariyer becerileri" şeklinde kategorize edilen üç temel beceri alanına yönelik görüşlerinin alınması, bu görüşlerden hareketle etkinliklerin planlanmasının öğretmen yetiştiren kurumlara ve alan yazına katkı sağlayacağı düşünülmektedir.

\section{Kaynakça}

Anagün, Ş.S., Atalay, N., Kılıç, Z., \& Yaşar, S. (2016). Öğretmen adaylarına yönelik 21. yüzyıl becerileri yeterlilik algıları ölçeğinin geliştirilmesi: Geçerlik ve güvenirlik çalışması. Pamukkale Üniversitesi Eğitim Fakültesi Dergisi, 40, 160-175. DOI: 10.9779/PUJE768

Arslan, M. M., \& Bayrakcı, M. (2006). Metaforik düşünme ve öğrenme yaklaşımının eğitimöğretim açısından incelenmesi. Milli Eğitim, 171, 100-108.

Aybek B., \& Yolcu E., (2018). İlkokul ve ortaokullarda görevli öğretmenlerin eleştirel düşünmeye ilişkin farkındalıkları. Yükseköğretim ve Bilim Dergisi/Journal of Higher Education and Science, 8(3), 567-573. DOI: 10.5961/jhes.2018.297

Aydın, İ. S., \& Pehlivan, A. (2010). Türkçe öğretmeni adaylarının "öğretmen" ve "öğrenci" kavramlarına ilişkin kullandıkları metaforlar. International Periodical for the Languages, Literature and History of Turkish or Turkic, 5(3), 818-842. 
Balc1, F. A. (2011). Metaphorical images of school: school perception of primary education superrvisors, Eurasian Journal of Educational Research, 44(Summer), 51-57.

Başar, S. (2018). Fen bilimleri öğretmen adaylarının fende matematiğin kullanımına yönelik özyeterlik inançları, 21. yüzyıl becerileri ve aralarındaki ilişkinin incelenmesi (Yükssek lisans tezi, Hacettepe Üniversitesi, Ankara). Erişim adresi: https://tez.yok.gov.tr/UlusalTezMerkezi/

Beers, S.Z. (2011). Teaching 21st century skills: An ASCD action tool. ASCD.

Bülbül, T., \& Gökçe Toker, A. (2015). Meslek lisesi öğrencilerinin metaforik okul algıları: İşlevselci bir yaklaşım. Ahi Evran Üniversitesi Kırşehir Eğitim Fakültesi Dergisi (KEFAD) 16 (2), 273-291.

Cerit, Y. (2008). Öğrenci, öğretmen ve yöneticilerin müdür kavramı ile ilgili metaforlara ilişkin görüşleri. Eğitim ve Bilim, 33(147), 3-13.

Creswell, J. W. (2016). Nitel araştırma yöntemleri. Ankara: Siyasal Kitabevi.

Çetinkaya, S., \& Eskici, M. (2018). Öğretmenlerin öğretmeye yönelik metaforik algıları. Akdeniz Eğitim Araştırmaları Dergisi, 12 (24), 253-271. DOI: 10.29329/mjer.2018.147.14

Çınar, F.S. (2019). Ortaokul öğretmenlerinin 21. yüzyıl becerilerine ilişkin algılarının ve görüşlerinin incelenmesi (Çorum ili Örneği) (Yüksek lisans tezi, Kafkas Üniversitesi, Kars). Erişim adresi: https://tez.yok.gov.tr/UlusalTezMerkezi/

Çırak, S. (2014). Ortaokul öğretmenlerinin öğrenci kavramına ilişkin metaforik algıları. Mustafa Kemal Üniversitesi Sosyal Bilimler Enstitüsü Dergisi, 11(27), 221-236.

Çırak Kurt, S., \& Yıldırım, İ. (2020). İlköğretim matematik öğretmenleri ile öğretmen adaylarının çeşitli kavramlara ilişkin metaforik algıları. Pamukkale Üniversitesi Eğitim Fakültesi Dergisi,48, 174-198. DOI: 10.9779/pauefd.450048

Çolak, M. (2018). Ortaokul fen bilimleri dersinin 21.yüzyıl becerilerini kazandırmadaki etkililiğine ilişkin öğretmen görüşleri (Kayseri ili örneği) (Yüksek lisans tezi, Erciyes Üniversitesi, Kayseri). Erişim adresi: https://tez.yok.gov.tr/UlusalTezMerkezi/

DiCerbo, K. (2014). Assessment and teaching of 21st century skills. Assessment in Education: Principles, Policy \& Practice, 21(4), 502-505. DOI: 10.1080/0969594X.2014.931836

Durukan, Ü. G., Hacıoğlu, Y., \& Dönmez Usta, N. (2016). Bilgisayar ve öğretim teknolojileri öğretmeni adaylarının "teknoloji” algıları. Journal of Computer and Education Research, 4 (7), 24-46.

Dündar, H., \& Karaca, E. T. (2013). Formasyon öğrencilerinin pedagojik formasyon programına ilişkin sahip oldukları metaforlar. Gazi Üniversitesi Endüstriyel Sanatlar Eğitim Fakültesi Dergisi, 30, 19-34.

Eker, C., Akar Elekoğlu, A., Kamar, P., \& Kamar, M. (2019). Ortaokul öğretmenlerinin 21. yüzyıl becerilerine yönelik yeterlik algılarının incelenmesi. Uluslararası Eğitim Bilimleri Dergisi, 6 (20), 26-37. DOI: 10.29228/INESJOURNAL.37804

Ekici, G., Abide, Ö. F., Canbolat, Y., \& Öztürk, A. (2017). 21. yüzyıl becerilerine ait veri kaynaklarının analizi. Eğitim ve Öğretim Araştırmaları Dergisi, 6(1).124-134.

Erdoğan, D. (2020). Türkçe öğretmen adaylarının 21. yüzyıl becerileri ile yaşam boyu öğrenme eğilimleri arasındaki ilişkinin incelenmesi (Yüksek lisans tezi, Zonguldak Bülent Ecevit Üniversitesi, Zonguldak). Erişim adresi: https://tez.yok.gov.tr/UlusalTezMerkezi/

Eryılmaz, S., \& Uluyol, Ç. (2015). 21. yüzyıl becerileri ışığında FATİH projesi değerlendirmesi. Gazi Eğitim Fakültesi Dergisi, 35(2), 209-229.

Facione, P.A. (2011). Critical thinking: What it is and why it counts: Insight Assessment. Retrieved

from 
https://www.student.uwa.edu.au/_data/assets/pdf_file/0003/1922502/Critical-ThinkingWhat-it-is-and-why-it-counts.pdf

Fadel, C., Bialik, M., \& Trilling, B. (2015). Four dimension education. The competence learner need to succeed. Boston: The Center For Curriculum Redesign.

Gezer, A. (2006). Soyut kavramların öğretiminde hayvan masallarının yeri (Yüksek lisans tezi, Marmara Üniversitesi, İstanbul). Erişim adresi: https://tez.yok.gov.tr/UlusalTezMerkezi/

Göksün, D. O., \& Kurt, A. A. (2017). Öğretmen adaylarının 21. yüzyıl öğrenen becerileri kullanımları ve 21. yüzyıl öğreten becerileri kullanımları arasındaki ilişki. Eğitim ve Bilim, 42(190), 107-130. DOI: http://dx.doi.org/10.15390/EB.2017.7089

Gürültü, E., Aslan, M., \& Alc1, B. (2018). İlköğretim öğretmenlerinin yeterliliklerinin 21. yüzyıl becerileri 1şığında incelenmesi. Akademik Sosyal Araştırmalar Dergisi, 6, (71), 543-560.

Jacobson-Lundeberg, V. (2016). "Pedagogical implementation of 21st century skills". Educational Leadership and Administration: Teaching and Program Development, 27, 82100. Retrieved from https://files.eric.ed.gov/fulltext/EJ1094407.pdf

Kaya, S. (2017). Lise öğrencilerinin 21. yüzyıl becerilerinin öğrenci tükenmişliği ve okul bağlılığ1 ile ilişkisi (Yüksek lisans tezi, Hacettepe Üniversitesi, Ankara). Erişim adresi: https://tez.yok.gov.tr/UlusalTezMerkezi/

Kaya, M. F. (2014). Sosyal bilgiler öğretmeni adaylarının çevre sorununa ilişkin algıları: Metafor analizi örneği. Turkish Studies, 9 (2), 917-931.

Kay, K., \& Greenhill, V. (2011). Twenty first century students need 21st century skills. In: G. Wan, \& D. M. Gut (Eds.), Bringing schools into the 21st century (pp. 41-65), Springer.

Keskin I., \& Yazar T. (2015). Examining digital competence of teachers within the context of lifelong learning based on of the twenty-first century skills. International Journal of Human Sciences, 12 (2): 1691-1711.

Korkmaz, F., \& Ünsal, S. (2016). Okul öncesi öğretmenlerin “Teknoloji” kavramına ilişkin metaforik algılarının incelenmesi. Mustafa Kemal Üniversitesi Sosyal Bilimler Enstitüsü Dergisi, 13(35), 194-212.

Kozikoğlu, İ., \& Altunova, N. (2018). Öğretmen adaylarının 21. yüzyıl becerilerine ilişkin özyeterlik algılarının yaşam boyu öğrenme eğilimlerini yordama gücü. Yükseköğretim ve Bilim Dergisi, 8 (3), 522-531. DOI: 10.5961/jhes.2018.293

Kuzu, A., Günüç, S., \& Odabaşı, H. F. (2013). 21. yüzyıl öğrenci özelliklerinin öğretmen adayları tarafından tanımlanması: Bir twitter uygulaması. Eğitimde Kuram ve Uygulama, 9(4), 436-455.

Küçük, A., \& Demir, B. (2009). İlköğretim 6-8. sınıflarda matematik öğretiminde karşılaşılan bazı kavram yanılgıları üzerine bir çalışma. Dicle Üniversitesi Ziya Gökalp Eğitim Fakültesi Dergisi, 13, 97-112.

Lakoff, G., \& Johnson, M. (2005). Metaforlar hayat, anlam ve dil. (Çev: Demir, G. Y.). İstanbul: Paradigma.

Lai, E. R., \& Viering, M. (2012). Assessing 21st century skills: Integrating research findings. Vancouver, B.C.: National Council on Measurement in Education.

Larson, L. C., \& Miller, T. N. (2011). 21st century skills: Prepare students for the future. Kappa Delta Pi Record, 47(3), 121-123. Retrieved from https://doi.org/10.1080/00228958.2011.10516575

Levine, P. M. (2005). Metaphors and images of classrooms. Kappa Delta Pi Record, 41(4), 172175. Retrieved from https://files.eric.ed.gov/fulltext/EJ724893.pdf 
Martinez, M.A., Sauleda, N., \& Huber, G.L. (2001). Metaphors as blueprints of thinking about teaching and learning. Teaching and Teacher Education, 17, 965-977. Retrieved from https://norbal.files.wordpress.com/2011/09/martinez-ao.pdf

Massengill, D., \& Mahlios, M. (2008). Pre-service teachers' metaphors of teaching and literacy. Reading Psychology, 29(1), 31-60. DOI: 10.1080/02702710701568397

Miles, M, B., \& Huberman, A. M. (1994). Qualitative data analysis: An expanded sourcebook. (2nd ed). Thousand Oaks, CA: Sage.

Millî Eğitim Bakanlığ1 (2017). Öğretmen strateji belgesi 2017-2023. Öğretmen Yetiştirme ve Geliştirme Genel Müdürlüğü. Erişim Adresi: http://oygm.meb.gov.tr/meb_iys_dosyalar/2017_07/26174415_Strateji_Belgesi_RG-Ylan_26.07.2017.pdf

Morgan, G. (1998). Yönetim ve örgüt teorilerinde metafor. (Çev: G. Bulut). İstanbul: MESS Yayınları.

Murat, A. (2018). Fen bilgisi öğretmen adaylarının 21. yüzyıl becerileri yeterlik algıları ile stem'e yönelik tutumlarının incelenmesi (Yüksek Lisans Tezi, Fırat Üniversitesi, Elâzı ğ). Erişim adresi: https://tez.yok.gov.tr/UlusalTezMerkezi/

Nalçacı, A., \& Bektaş, F. (2012). Öğretmen adaylarının okul kavramına ilişkin algıları. Ahi Evran Üniversitesi Kırşehir Eğitim Fakültesi Dergisi, 13(1), 239-258.

Narin, N., \& Aybek, B. (2010). İlköğretim ikinci kademe sosyal bilgiler öğretmenlerinin eleştirel düşünme becerilerinin incelenmesi. Çukurova Üniversitesi Sosyal Bilimler Enstitüsü Dergisi, 19 (1), 336-350.

Orhan Göksün, D. (2016). Öğretmen adaylarının 21. yüzyıl öğreten becerileri ve 21. yüzyıl öğrenen becerileri arasındaki ilişki (Doktora tezi, Anadolu Üniversitesi, Eskişehir). Erişim adresi: https://tez.yok.gov.tr/UlusalTezMerkezi/

Örten, D., \& Erginer, E. (2016). Türkiye'de eğitimde program geliştirme alanındaki öncü akademisyenlerin eğitimde program geliştirmeye ilişkin metaforik algıları. Uluslararası Toplum Araştırmaları Dergisi, 6(11), 387-414.

Örücü, D. (2014). Öğretmen adaylarının okul, okul yönetimi ve Türk eğitim sistemine yönelik metaforik algıları. Kuram ve Uygulamada Eğitim Yönetimi, 20 (3), 327-358.

Özbaş, B., \& Aktekin, S. (2013). Tarih öğretmen adaylarının tarih öğretmenliğine ilişkin inançlarının metafor analizi yoluyla incelenmesi. Eğitimde Kuram ve Uygulama, 9 (3), 211228.

Özdemir, S., \& Akkaya, E. (2013). Genel Lise Öğrenci ve Öğretmenlerinin Okul ve İdeal Okul Algılarının Metafor Yoluyla Analizi. Kuram ve Uygulamada Eğitim Yönetimi, 19 (2), 295322.

Partnership for 21st Century Learning P21 (2019). Framework for 21st Century Learning. Retrieved from http://static.battelleforkids.org/documents/p21/P21_Framework_Brief.pdf

Patton, M. Q. (2002). Qualitative research \& evaluation methods (3rd ed.). Thousand Oaks, CA: Sage Publications, Inc.

Pellegrino, J. W. \& Hilton M. L. (2012). Education for life and work: Developing transferable knowledge and skills in the 21st century. National Research Council of the National Academies, The National Academies Press, Washington, D.C.

Saban, A. (2009). Öğretmen adaylarının öğrenci kavramına ilişkin sahip oldukları zihinsel imgeler. Türk Eğitim Bilimleri Dergisi, 7 (2), 281-326.

Saban, A. (2008). Okula ilişkin metaforlar. Kuram ve Uygulamada Eğitim Yönetimi, 55, 459496. 
Seferoğlu, G., Korkmazgil, S., \& Ölçü, Z. (2009). Gaining insights into teachers' ways of thinking via metaphors, Educational Studies, 3, 323-335.

Selçuk, G. (2018). Türkçe öğretmen adaylarının öğretim teknolojileri ve materyal tasarımı dersine ilişkin metaforik algılarının incelenmesi. Akdeniz Eğitim Araştırmaları Dergisi, 12 (26), 526-543. DOI: 10.29329/mjer.2018.172.26

Semerci, Ç. (2003). Eleştirel düşünme becerilerinin geliştirilmesi. Eğitim ve Bilim, 28 (127), 6470.

Semerci, Ç. (2007). Program geliştirme kavramına ilişkin metaforlarla yeni ilköğretim programlarına farklı bir bakış. Cumhuriyet Üniversitesi Sosyal Bilimler Dergisi, 31 (40), $125-140$.

Silva, E. (2009). Measuring skills for 21st century learning. The Phi Delta Kappan, 90 (9),630634.

Soland, J., Hamilton, L. S., \& Stecher, B. M. (2013). Measuring 21st century competencies guidance for educators. Santa Monica, CA: RAND Corporation.

Thomas, L., \& Beauchamp, C. (2011). Understanding new teachers' professional identities through metaphor. Teaching and Teacher Education 27(4), 762-769.

Trilling, B., \& Fadel, C. (2009). 21st century skills: Learning for life in our times. Francisco: Jossey-Bass.

Tünkler, V., Tarman, B., \& Güven, C. (2016). Vatandaşlık ve demokrasi eğitimi öğretim programında yer alan soyut kavramların ve değerlerin öğrencilere kazandırılmasına ilişkin metaforik bir yaklaşım. Eğitim ve Bilim, 41(185), 123-145. DOI: http://dx.doi.org/10.15390/EB.2016.6031

Yalçın, S. (2018). 21. yüzyıl becerileri ve bu becerilerin ölçülmesinde kullanılan araçlar ve yaklaşımlar. Ankara Üniversitesi Eğitim Bilimleri Fakültesi Dergisi, 51(1), 183-201. DOI:10.30964/auebfd.405860

Yeni, G. (2018). 21. yüzyıl becerileri eğitiminin yabancı dil öğretmenlerinin eğitim teknolojisi ve materyal geliştirme yeterliklerine ilişkin algılarına etkisi (Yüksek lisans tezi, İstanbul Üniversitesi-Cerrahpaşa, İstanbul). Erişim adresi: https://tez.yok.gov.tr/UlusalTezMerkezi/

Yıldırım, A. (2018). Türkiye'de Öğretmen Yetiştirme Süreci. Erişim Adresi: https://www.ogretmensitemiz.com/egitim/turkiyede-ogretmen-yetistirme-surecih1716.html

Yıldırım A., \& Şimşek H. (2013). Sosyal bilimlerde nitel araştırma yöntemleri. (9.Baskı). Ankara: Seçkin Yayınevi.

Yob, I. M. (2003). Thinking constructively with metaphors. Studies in Philosophy and Education, 22, 127-138. DOI: 10.1023/A:1022289113443

Yüner, B., \& Özdemïr, M. (2017). Metaforik Okul Algısı ile Okulu Terk Eğilimi Arasındaki İlişkinin Öğrenci Görüşlerine Göre İncelenmesi. Gazi Üniversitesi Gazi Eğitim Fakültesi Dergisi, 37 (3), 1041-1060. DOI: 10.17152/gefad.303842 